\title{
BURIAL PRACTICES AT LAPIN̦I CURONIAN \\ CREMATION CEMETERY, WEST LATVIA, AT THE CLOSE OF THE IRON AGE AND IN THE MIDDLE AGES (12TH-14TH/15TH CENTURIES)
}

\section{INGA DONIN,A, ${ }^{1,}$ NORMUNDS STIVRINS, ${ }^{1,2}$ VALDIS BĒRZIN̦Š1}

\author{
${ }^{1}$ Latvian Institute of History, University of Latvia, Kalpaka bulvāris 4, LV-1050 Riga, Latvia \\ ${ }^{2}$ University of Latvia, Jelgavas iela 1, LV-1004, Riga, Latvia. Tallinn University of Technology, Ehitajate tee 5, EE-19086, Tallinn, \\ Estonia. Lake and Peatland Research Centre, Puikule, Aloja district, Latvia
}

\section{Keywords}

Lapini cemetery, cremation burials, Curonians, burial ritual, Late Iron Age, Middle Ages, non-pollen palynomorphs, pollen, wood charcoal

\begin{abstract}
This article examines cremation cemeteries in west Latvia from the end of the Late Iron Age and the Middle Ages (12th-14th/15th centuries). During this period, cremation graves constituted the dominant burial form in the region. We have selected as a case study Lapini cemetery, which reveals additional details relating to cremation cemeteries of west Latvia. The aim of the article is to provide further insights into burials of this kind in the Baltic region, which correspond in time to the Curonian expansion in northwest Latvia, followed by the conquest by the Crusaders and the change of religion and burial practices in present-day Latvia. For a better understanding of the environmental conditions at the time of use of the cemetery, taxonomic analysis has been undertaken of the charcoal used as fuel for cremation, as well as an analysis of pollen and non-pollen palynomorphs from cremation graves. Lapini is so far the only Curonian cemetery in present-day Latvia where such analyses have been conducted. This has given us a new understanding of the funeral rituals performed on the burial site, and the formation process of cremation cemeteries.
\end{abstract}

\section{Introduction}

This article examines Curonian burial traditions in west Latvia, focusing on cremation graves at the Lapini cemetery (Fig.1), which was in use from the 12th to the 14 th/15th centuries $\mathrm{AD}$. Cremation was established as the dominant form of burial in west Latvia at the end of the Late Iron Age, and continued well into the second half of the Middle Ages. The Late Iron Age began in Latvia in 800 $\mathrm{AD}$, and ended with the first Crusades at the close of the 12th century, these being considered as marking the beginning of the Middle Ages in Latvia. The purpose of the article is to obtain a deeper understanding of this type of burial in the Baltic region, based on the archaeological evidence from Lapini. The first cremation burials from this period appear in the present-day northwest in the second half of the 11th century, thus coinciding with the beginning of Curonian expansion into the territories populated by Baltic Finns (Vends). This was later followed by the conquest by the Crusaders of the indigenous lands, with a change to Christian religious and burial practices.

An analysis of pollen and non-pollen palynomorphs or microfossils from two cremation burials was carried out in order to establish the environmental conditions at the time of use of Lapini cremation cemetery. Also, 43 charcoal fragments from seven excavation areas containing cremation graves were examined, in order to shed a light on the environment and the use of firewood in cremation rituals. Lapini cremation cemetery is the first Curonian burial site of this period in present-day Latvia for which these kinds of analysis have been carried out.

\footnotetext{
${ }^{\star}$ Corresponding author. E-mail: inga.donina@lu.lv
} 


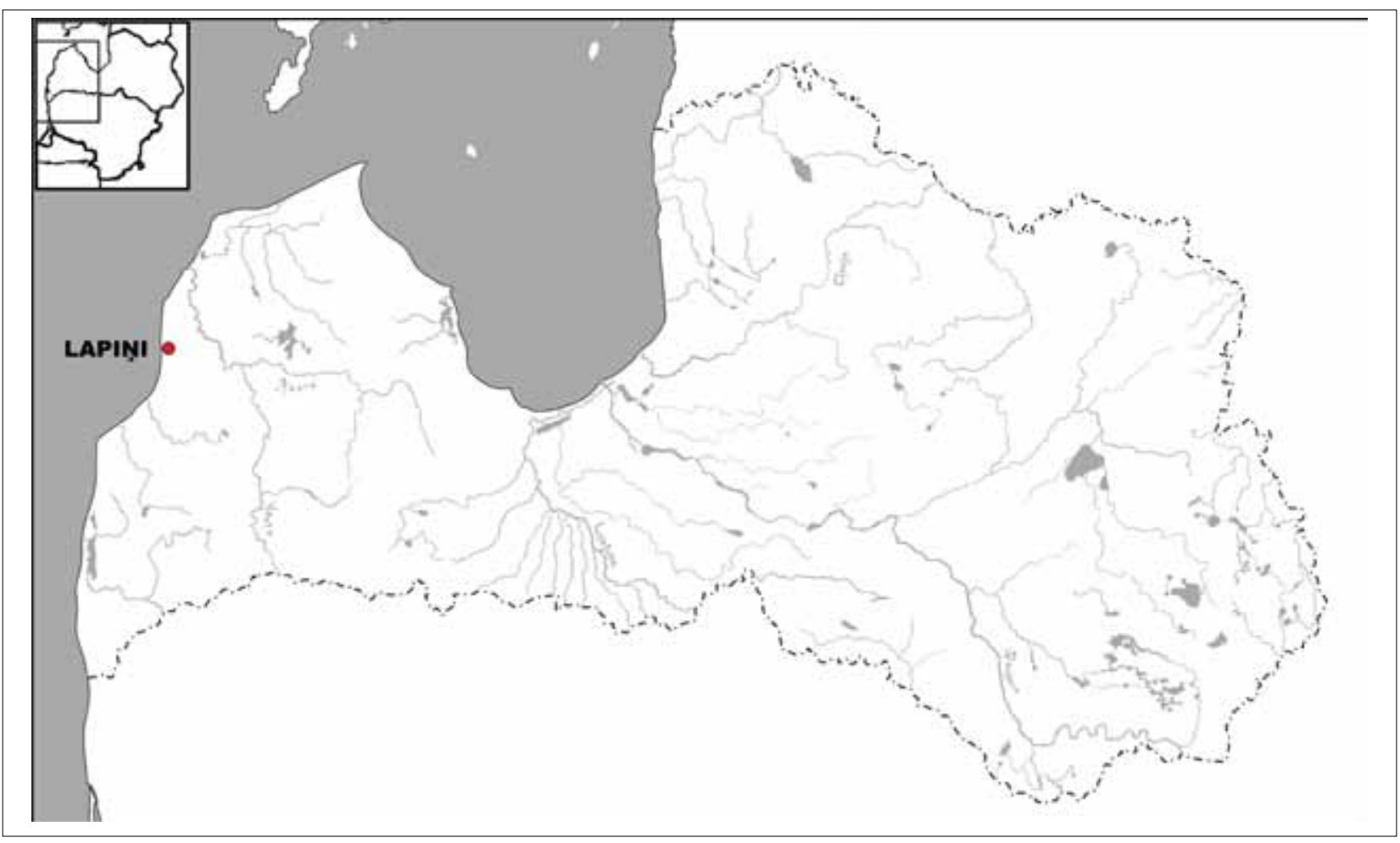

Figure 1. The location of Lapini cemetery on a map of Latvia.

\section{Cremation burials \\ in the Baltic Sea region}

In the archaeological context, the term 'cremated' refers to a ritualistic complex of actions involving the deliberate destruction of the deceased by fire (McKinley and Bond 2001, p. 281). Cremation is the destruction of the body by fire at high temperature, until it is reduced to bone fragments and ashes (Hudson 2013, p. 4), which are then subjected to a particular burial ritual. The complete destruction of the body by fire is not possible.

Cremation has been an important funeral ritual for many cultures around the world for centuries. The earliest cremated burials in Europe are known from the Mesolithic. In Europe, after the conversion to Christianity, from the 5 th century onwards, and in Scandinavia from the 10th century onwards, cremation as a form of burial was gradually forgotten (Lemmers 2012, p. 81; Sigvallius 2005, p. 415).

Cremation cemeteries constitute the dominant form of burial during the Middle Ages and the Late Iron Age (300-1100 AD) in Finland, Estonia and the Karelian Isthmus of Russia (Wickholm 2005, p. 31). Cremation likewise prevailed in the Viking Age and in the 12th century on Saaremaa and in mainland Estonia (Mägi 2015, p. 51). In present-day Latvia and Lithuania, on the eastern shore of the Baltic Sea, cremation as a form of burial appears sporadically among various tribes during the Iron Age and the Middle Ages. For example, in central Lithuania, cremation graves occur starting from the 5th or 6th century up to the 14 th century. Cremation was practised in the eastern part of present-day Lithuania, and the dead were in barrow cemeteries, from the 4 th to the 12 th century, whereas after the 12th century cemeteries were used. In Samogitia, cremation was widespread in the 12th century and up to the time of Christianisation in 1413 (Mägi 2002, pp. 16-18; Kurila 2009, p. 8). In the Liv cemeteries of the Late Iron Age in central and eastern Latvia, 20-30\% of burials were cremations, and among the Latgallians, Selonians and Semigallians, the proportion was even lower. After the Crusades and the Christianisation of presentday Latvia, the tradition of cremation disappeared earlier in these regions. Separate cremation graves can be found in Latgallian and Liv territories up to the 13th or 14th centuries, and cremation burials occur in southeast Latvia from the end of the 14th up to the early 16th century (Muižnieks 2016, pp. 61-63).

In western parts of Lithuania and Latvia, in the territories inhabited by the Curonians, cremation occupied an important place in the burial tradition. Although the first signs of the cremation of the dead as a form of burial in Curonian culture can be found starting from the late 8th century, in the southern Curonian lands, cremation was practised for a long time in parallel with inhumation (Bliujienè 2016, pp. 278-279; Griciuvienè 2009, p. 233). 
From the second half of the 11th century, cremation became the dominant form of burial, persisting until the $14 \mathrm{th}$, and in some places until the beginning of the 15th century (Asaris et al., 2008, p. 57; Griciuviene 2009, p. $233)$. Starting from the early 13 th century, under the influence of the Christian faith, there was a gradual return to inhumation. However, this process was very slow, because even in the 13th and 14th centuries, the cremation of the dead was widely practised (Griciuviene 2009 , pp. 88, 233, 392; Muižnieks 2008, pp. 35-38, 42).

The burials at Lapini (Fig. 1) all relate to Curonian culture, which up to the 10th century occupied the entire seaboard of present-day Lithuania and the southwest part of today's Latvia. From the beginning of the 11th century, as the population grew, Curonian expansion northward began, gradually reaching the furthest northwest part of present-day Latvia. From the mid-11th century, the Curonians began to infiltrate the area inhabited by the Baltic Finns (Asaris 1996, pp. 38-42). As a result of this expansion, the Curonians gradually intermingled with and assimilated the local cultures, so that the influence of their material culture appears in power centres that had previously been Finnic, such as Talsi and Mežite. As a result of these processes, one section of the inhabitants (referred to as the Vends in the Chronicle of Henry) moved to the lower Daugava area, and later to Cèsis in the Vidzeme region. The burial ground discussed here is located in the western part of Latvia, where cremation was practised in the period from the 11th until the turn of the 15th century (Mugurēvičs 1999, p. 64; Griciuvienè 2009, pp. 88, 462; Plankājs 2017).

In Latvian archaeology, the beginning of the Late Iron Age is set at $800 \mathrm{AD}$, lasting until the end of the 12th century. ${ }^{1}$ The Middle Ages are regarded as beginning around the turn of the 13th century (Šnē 2011, pp. 139-140). The Medieval period in the east Baltic (1198-1561) starts with the Crusades in the 13th century, where the aim of the military order and the bishop was to convert the local pagan tribes to Christianity by conquering present-day Estonia, Latvia and western Lithuania. The conquest and subsequent colonisation of former tribal territories resulted in significant changes to the ownership, organisation and administration of the landscape, with subsequent changes in patterns of land use from the 13th to the 16th century (Stivrins et al., 2016, pp. 61-69). As can be seen from written sources and various treaties between the Curonians, the Livonian Order and the Bishop of Curonia, there was a major effort at this time to convert the Curonians. However, the study of Curonian burial practices shows that they were among the groups holding on the longest to their pagan traditions, namely by cremating

\footnotetext{
${ }^{1}$ In the works Latvijas PSR arheologija and Latvijas senākā vesture: 9. g. t. pr. Kr. 1200. g. the Late Iron Age is identified as the period 800 to $1200 \mathrm{AD}$, and is referred to in certain publications as the Early Middle Ages.
}

their dead, which is not only reflected in the archaeological evidence, but is also described by written sources. For example, the Chronicle of Henry, compiled between 1224 and 1227, in the account of a Curonian attack on Riga in 1210, describes how: 'The Curonians retreated from the town, gathered up their dead, and, having returned to the ships, crossed to the other bank of the Daugava. There they spent three days in peace, burned their dead and mourned them' (Indriķa hronika 1993, pp. 29, 139; Asaris 2008 p. 135). The Curonian practice of cremation is described by the French traveller Guillebert de Lannoy in the early 15th century: among the Curonians 'although they have been converted to Christianity by force, there is a sect that cremates its dead, dressed and adorned with their finest jewellery, at the place of burial in a nearby grove or wood, building a pyre of pure oak firewood; and they consider that if the smoke rises directly to heaven, then the soul is saved, but if it is carried to the side, then the soul is lost' (Šturms 1938, p. 93; Asaris 2008, p. 135). The context of this account indicates that cremation was by that time no longer a widespread tradition, but rather a custom observed by part of the Curonian population, who instead of practising inhumation as required by the Christian Church, continued to cremate the dead. Stray finds and cremation graves discovered at burial sites in the Courland (Kurzeme) region of west Latvia dating from the 14 th and 15th centuries testify unequivocally to the persistence of this ancient pagan funeral tradition. The Church regarded cremation as inconsistent with the Christian funeral rite (Muižnieks 2008, p. 42).

\section{Typical features of Curonian cemeteries}

Curonian cremation graves show great variety, both in terms of the kind of burial site and the type of grave. Researchers distinguish underwater burials as a separate type of Curonian burial, although so far only one such burial site has been found: Lake Vilkmuiža at Talsi. There, the remains of the funeral pyre (charcoal and grave goods, fused and deformed artefacts) occur on the lake bed, ${ }^{2}$ ten to 25 metres from the shore in a 70 to 100 -metre-long strip parallel with the shoreline. Thousands of artefacts dating from the period from the 11th to the 15th century have been caught in fishing gear and trawled from the lake (Mugurēvičs 1968, p. 19; Doniņa 2016, pp. 7-18).

The rest of the Curonian cemeteries are characterised by cremation graves. The deceased could be cremated in the grave itself together with the grave goods, or cremated elsewhere, the latter being the more common practice. When cremation was performed elsewhere, the

\footnotetext{
2 There are indications of separate finds of burnt bones from the lake, but it is quite possible that the methods used to retrieve artefacts from the lake in the 1930s were unsuitable for recovering bones.
} 
cremated remains, consisting of a mixture of coal, burnt bone and grave inventory pieces (in most cases molten and deformed artefacts, broken, bent and, in the case of later graves, also cut or hacked to pieces), were collected and buried in a pit grave. The ashes might also be scattered in a wide area on the surface of the ground. In some cases, the cremated remains were put in a pottery vessel or urn and buried (Asaris, et al., 2008, p. 58; Griciuvienè 2009, p. 234). In such cases, the grave goods would be placed both inside and around the urn. The remains of the funeral pyre could also have been placed in a birch-bark container or a small wooden box, or wrapped in cloth (Asaris et al., 2008 , p. 58). The grave may vary in depth, from a few centimetres to 1.5 metres, and the shape in plan shows great variety: small round pits, large irregular pits, and regular rectangular pits. Among the chronologically later cremation burials, several types of individual and collective graves may be distinguished. Individual cremation graves are usually small in area, measuring one to four square metres. By contrast, collective graves may in some cases exceed ten square metres, containing up to seven simultaneous burials (Mugurēvičs 1968, p. 19; Žulkus 2004, pp. 168-171).

In terms of the grave inventory and burial practices, right up to the early 14th century, Curonian cremation graves display similar features and parallels to those of the Late Iron Age. Miniature objects, drinking horns, horse-trappings, tools and pottery are still present in the graves from the 13th century. Most of these objects and classes of object are missing in late cremation graves. Broken and deliberately damaged objects are less common in cremation graves from the 14th and 15th centuries. A typical item in late female cremation graves is the annular brooch, with an increase in the number of such brooches in burials starting from the mid-14th century. Other items found together with these include penannular brooches (with nail, polyhedral, rolled-back or lily terminals), fingerrings, twisted neck-rings, coin pendants, ribbon-like and spiral bracelets, awls and knives. Shoe buckles are found in women's graves, which, judging from similar finds from the same period in inhumation graves, constitute a typical element of the footwear used in Courland in the late 14 th and early 15 th century. Bracelets with animal heads and neck-rings disappear from men's burials, these being common finds in graves from the 13th century. Neither are there any swords, weights for scales, keys and locks, scythes, or horse-trappings in burials from the 14th and 15th centuries. Penannular brooches and finger-rings are predominant in men's graves, while the tools, everyday utensils and weapons include knives, fire-steels, spears and axes (Muižnieks 2008, pp. 38-39).

\section{Lapiņi cemetery}

The investigation of the Curonian burial site of Lapini can serve as a case study, giving new insights into cremation cemeteries from the Late Iron Age and the Middle Ages in west Latvia. This is actually a double archaeological monument, where the Late Iron Age/Medieval cemetery, belonging to the late period of Curonian cremation burials, is located on the same site as a Stone Age settlement. Lapini is in the west of present-day Latvia, approximately two kilometres from the Baltic Sea (Fig. 1). The first indications of an archaeological site appeared in 2011, when an archaeological survey along a newly built forest road yielded Stone Age finds, and the cemetery was discovered in 2012 when the archaeological site was revisited. Both the settlement and the cemetery suffered serious disturbance as a result of the construction of the road. Archaeological excavations were undertaken by the Institute of Latvian History of the University of Latvia in 2012, 2014 and 2015, under the direction of Valdis Bērziņš and Inga Donina (Fig. 2). This location is thought to have been occupied initially in the 9th millennium BC (early Middle Mesolithic), corresponding to the time of the peak of the Ancylus Lake stage of the Baltic Sea basin, when it was located on the coast of the ancient Ventspils Bay, with evidence of human activity also at circa 5000 BC, the beginning of the early Neolithic (Bērziņš and Doniņa 2014, p. 10). Charcoal samples taken in a pit within the limits of the burial ground have been dated to around the time of Christ, which in Latvia corresponds to the early part of the Iron Age. ${ }^{3}$ In the absence of other evidence of human presence at Lapini during this period, the charcoal could be interpreted as evidence of a forest fire (Bērziňš et al., 2016, p. 13). This article will not consider the Stone Age settlement, focusing on an analysis of the Curonian cemetery.

An area of approximately 110 square metres of the cemetery has been investigated, of which the disturbed area constituted about 40 square metres. In some places, the graves had been completely destroyed, while in other parts only the top of the soil had been disturbed (Fig. 3). Based on the size of the investigated area and the distribution of the finds, the total area of Lapini cemetery may be estimated at 2,000 to 3,000 square metres.

The cremated remains at Lapini were generally scattered over a wide area, and were discovered immediately below the surface of the ground. Within the excavated area, the dark charcoal patches overlapped, preventing the exact

\footnotetext{
3 Poz-72721, conventional 14C age 1965 \pm 30 . Calibrated date: 42 $\mathrm{BC}$ - AD 85 (94.5\% probability) or $110-115 \mathrm{AD}$ (0.9\% probability); Poz-72723, conventional 14C age: $2050 \pm 30$. Calibrated date: 166 BC - AD 20 (94.5\% probability). Dates cited here and below calibrated using OxCal v4.2.3 (IntCal13 curve).
} 


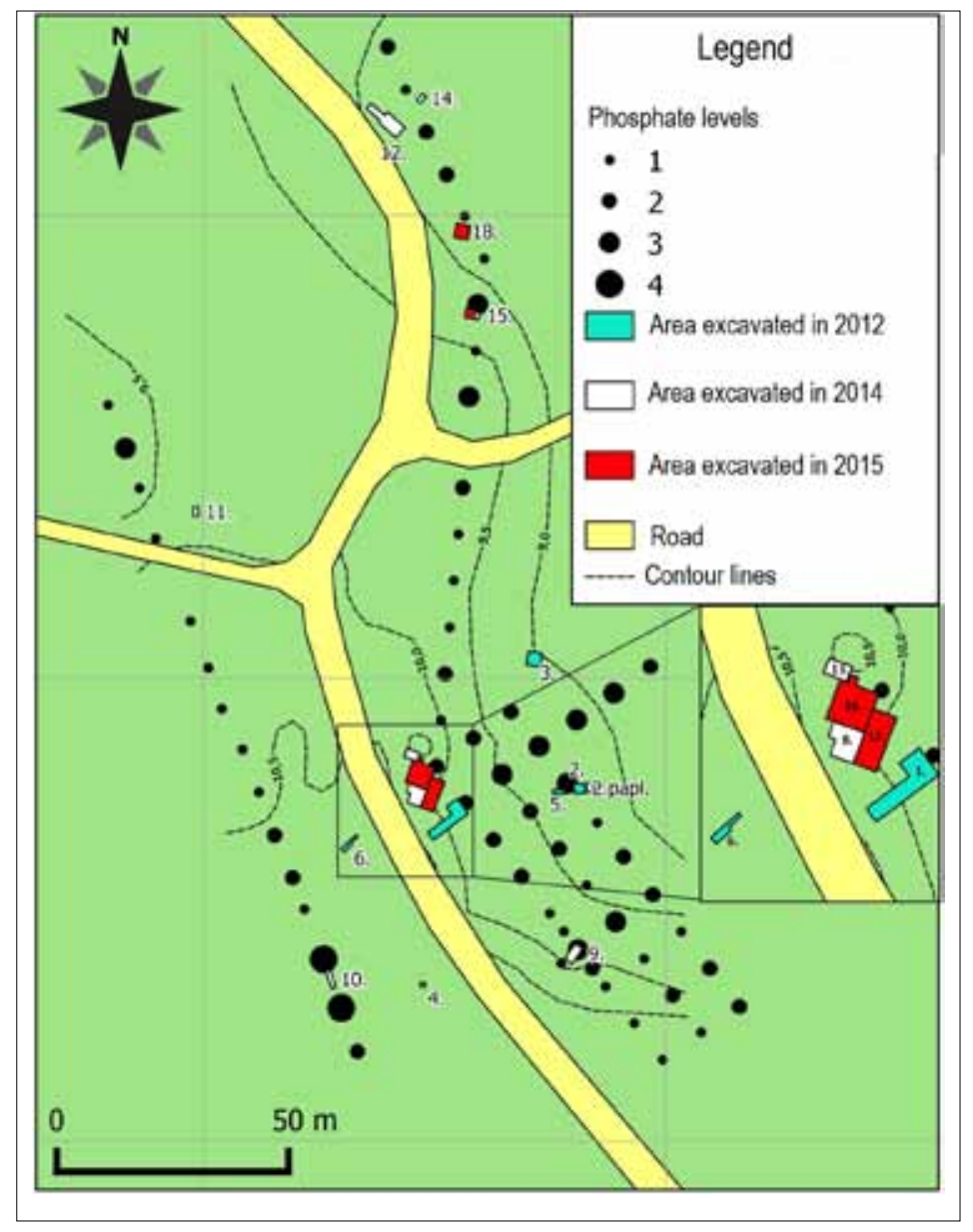

Figure 2. The layout of archaeological trenches at the Lapiṇi site (drawing by M. Kalniņš).

delimitation of the grave boundaries. When some of the charcoal layer was removed, darker charcoal-rich areas emerged, which in this case were assumed to be graves. In total, about 11 possible graves could be identified in the excavated area. These all showed a common pattern, where the charcoal layer, revealed immediately below the humus layer, varied in thickness from about one to 20 centimetres. Those of the charcoal-rich areas (graves) that could be separately distinguished each occupied approximately one to four square metres. In some cases, they were even larger, and extended into the unexcavated part of the cemetery. There was no discernible consistency in the orientation of these charcoal patches. The graves produced only separate burnt bones, and the hand-formed pottery and likewise the artefacts uncovered here are very fragmentary.

An exception among the exposed charcoal patches is a presumed grave (No 5) in the form of a small pit-like depression extending about 20 centimetres into the subsoil and occupying an area of 1.5 square metres. The artefacts found here include an animal-claw pendant, a round pendant, pottery, and a large chunk of charred wood, to which a glass bead had fused. The animal-claw pendant found in the grave had been suspended from a chain, without a bronze setting. A round pendant attached to a chain was found next to it. Animal-claw pendants are typical jewellery items from the second half of the 14th and the 15 th century. Such pendants of bear, lynx or wolf claw are most commonly found in women's graves, usually one per grave, with some exceptions (Muižnieks 2016, p. 148). The artefacts and pottery were revealed at the periphery of the grave, as were two fragments of charcoal identified as pine. It should be noted that the humus layer in this area had been disturbed during road construction. A piece of alder charcoal 44 centimetres long and nine centimetres thick, which had a purple glass bead fused to it, gave a radiocarbon date of $893-1154$ AD. ${ }^{4}$ This piece of charcoal was deeper in the natural subsoil than any of the other finds. So far, no artefacts dating from earlier than the 12th century have been found in the cemetery, nor is Lapini cemetery believed to have been established in the area before the 12th century. The dating suggests that this specimen relates to the beginning of the period of use of the cemetery, the 12th century. However, the age of the piece

\footnotetext{
4 Th-3587, conventional ${ }^{14} \mathrm{C}$ age: $1025 \pm 55$ g. Calibrated date: AD 893-1059 (74.0\% probability) or AD 1065-1154 (21.4\% probability).
} 


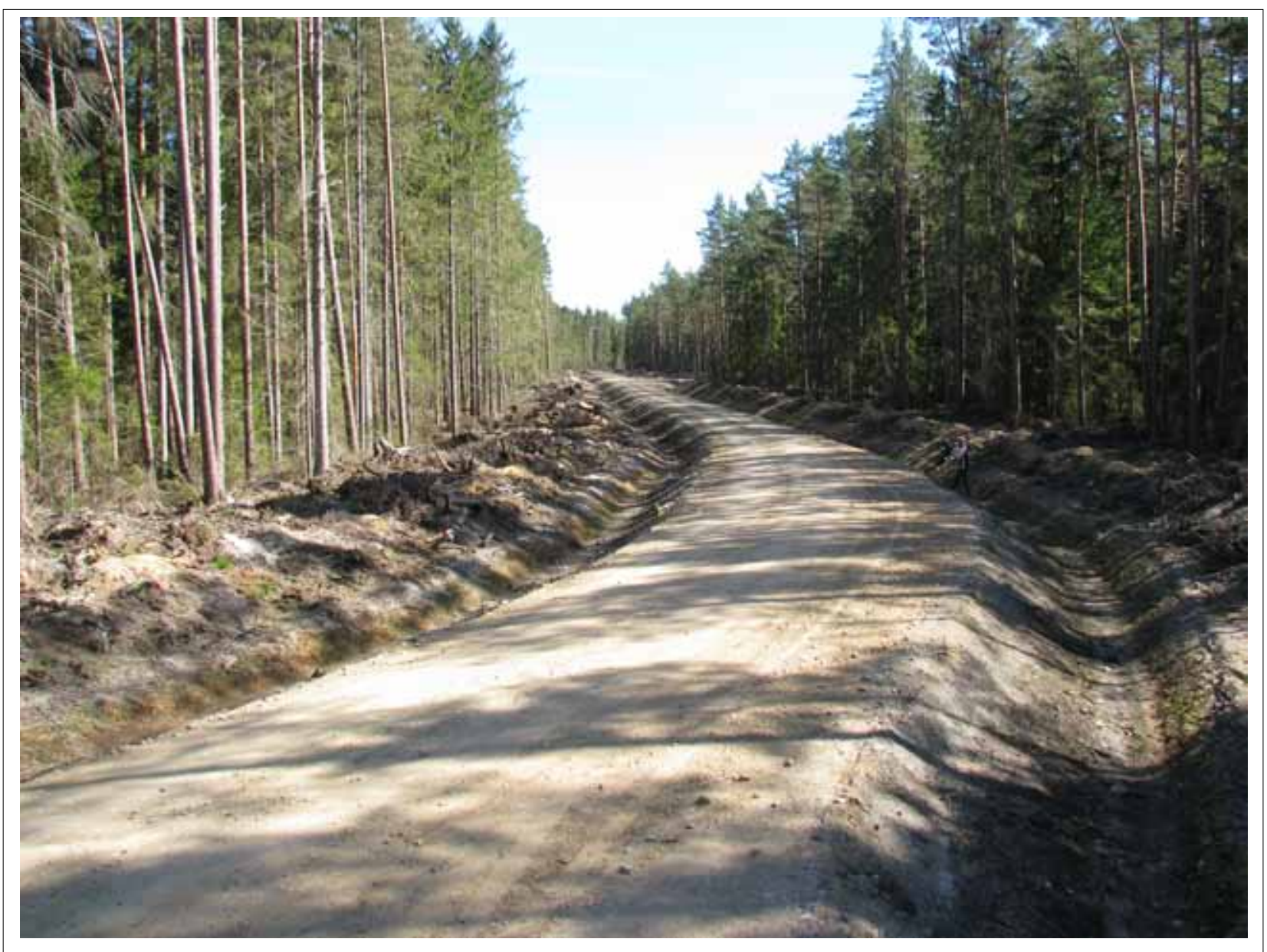

Figure 3. Lapini cemetery from the northwest in 2012 (photograph by V. Bērziṇš).

of charcoal does not match the time of use of the animal claw and round pendant recovered from the grave, i.e., the second half of the 14 th or the 15 th century. Such a 'mismatch' can probably be explained in terms of the digging of a later grave in the same location as an earlier one. Such cases are known in other Curonian cremation cemeteries, such as Kazdangas Roni, where cremation graves from the 13th and 14th centuries were found among earlier burials dating from the 12th and 13th centuries (Muižnieks 2008, p. 42).

One of the graves discovered in the cemetery (No 3) contained a coffin (Fig. 4). In this case, the deceased had been cremated elsewhere, and the remains buried in a wooden coffin measuring about 1.6 by 0.5 metres. There was almost no trace of cremated bone: only some very small and thin brown bone fragments. The wooden coffin had been buried in a 0.7 -metre-deep grave measuring 1.7 by 0.6 metres, with rounded corners (oriented N-S). The only artefact from this grave was a small amber bead uncovered at the southern end of the coffin. The coffin was made of deciduous wood (of indeterminate species) without nails. An AMS ${ }^{14} \mathrm{C}$ date of the charcoal from the coffin (a sample from the branch from an ash tree) gave a date of 1150-
$1260 \mathrm{AD}\left(90.5 \%\right.$ probability). ${ }^{5}$ The backfill of the grave contained fragments of hand-formed pottery, as is found in most Curonian cremation graves, along with two burnt bone fragments. The pottery and bone are believed to belong to an adjacent grave (No 4), which had been partially destroyed when the grave with the coffin was dug. Grave 4 contained a small number of artefacts, mainly fused pieces of bronze, along with one ribbon bracelet, sherds of handformed pottery, and two burnt bone fragments. A piece of pine charcoal from the partially destroyed grave was dated by AMS ${ }^{14} \mathrm{C}$ to $1115-1220 \mathrm{AD}$ (59.5\% probability). ${ }^{6}$ Pollen and non-pollen analysis was performed on these two burials (see the section 'Palynological and palaeobotanical analyses').

This is currently the only Curonian cremation grave known from this period in present-day Latvia where the cremated remains were buried in a coffin. Typically, cremated remains and grave inventory are scattered over a

5 Poz-72722, conventional 14C age: $850 \pm 30$ BP. Calibrated date: AD 1150-1260 (90.5\% probability) or AD 1050-1080 (5.2\% probability).

6 Poz-72724, conventional 14C age: $890 \pm 30$ BP. Calibrated date: AD $1115-1220$ (59.5\% probability) or AD 1040-1110 (35.9\% probability). 


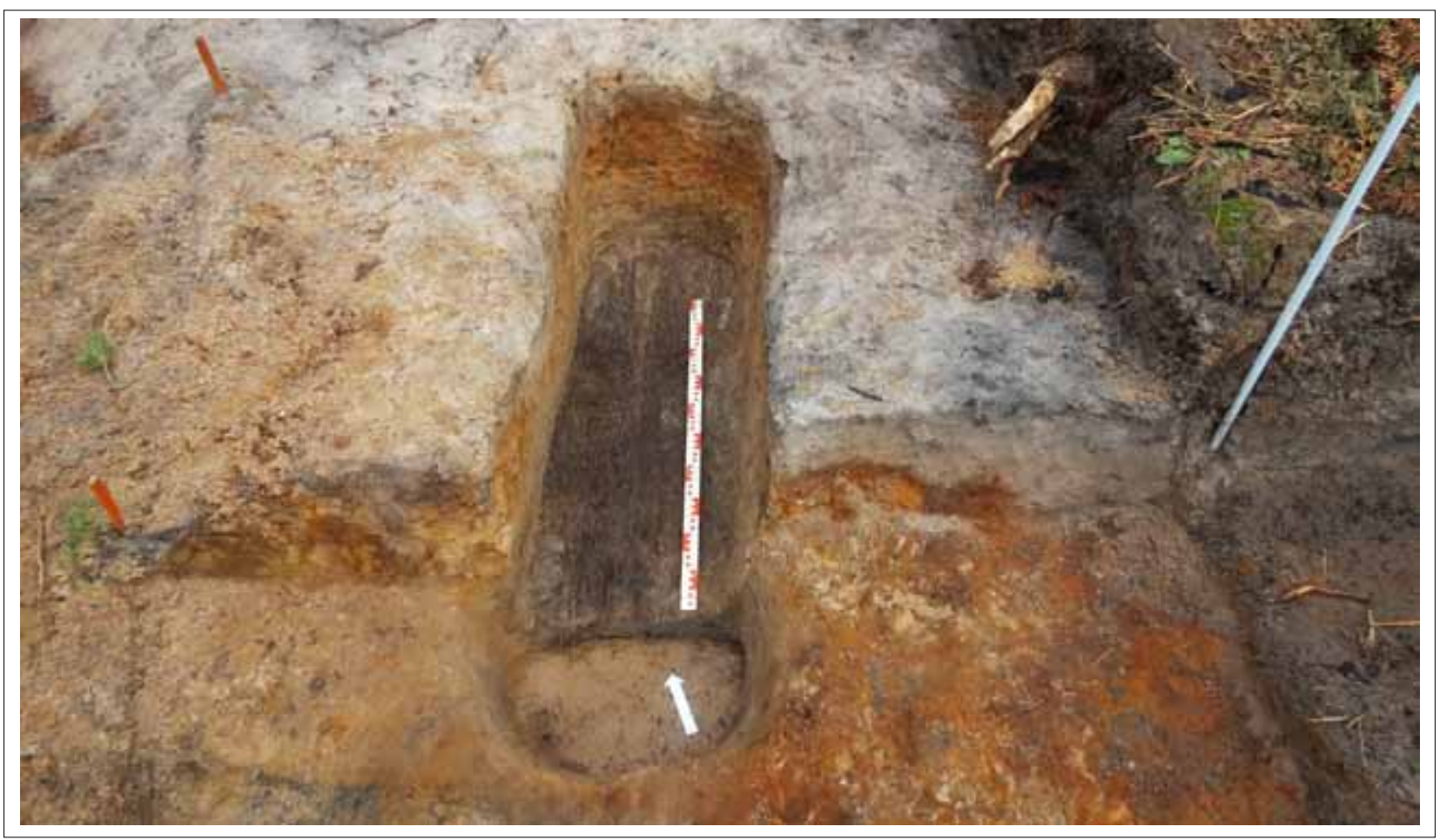

Figure 4. Grave 3. The remains of a cremation grave with a coffin (photograph by I. Donina).

wide area on the surface of the ground, buried in small pits, or placed in larger pits of various shapes and sizes, but without a coffin. For example, at Popes Lazdas, a cemetery from the late 13th or the first half of the 14th century, a female and male double burial was found in a 1.2-metredeep conical pit oriented W-E, which had a lining of clay. The other five cremation graves discovered there, dated to the 13 th or 14 th centuries, were revealed 25 to 30 centimetres below the arable layer, presenting irregularly shaped charcoal-rich areas with an extent of two/three by two/2.5 metres (Lūsēns 2000, p. 128).

It should be assumed that in this case at Lapini, the deceased was cremated at a specific cremation site, the remains (ash and burnt bone fragments) being collected and put into the coffin. Some cremation burials in coffins have been found in the southern part of the Curonianpopulated area, where they relate to the period of transition from inhumation to cremation (Asaris 2008, p. 58). A double effort was applied in burying this individual: firstly, in stacking the pyre and cremating the body, after which the cremated remains were collected from the cremation site, as with other Curonian cremation burials; and secondly, in making a coffin, which was not common practice in the Curonian burial tradition. We can only speculate about the reasons behind the choice to bury the deceased in this way. It might have been a person who fell in a distant territory, or someone who had married into or was a newcomer to Curonian society, or the burial could be explained in terms of the transition from burial in ac- cordance with the pagan tradition to burial in line with the Christian tradition.

A large number of artefacts have been found in the destroyed part of the cemetery, where in some areas bulldozing has relocated whole blocks of earth. A grave with artefacts typologically dated to approximately the 14th or 15th century (Fig. 5) was moved in this manner (artefact concentration 5) as an intact block of earth. ${ }^{7}$ Unlike other graves, this grave contained a relatively large amount of burnt bone ( $270 \mathrm{~g})$. As the grave had been damaged during road construction and was only partially excavated, it is likely that the amount of bone was initially even larger. The skeletal material has been determined as belonging to an individual over the age of $15 .^{8}$

The recovered bone included one burnt animal bone (sheep/goat), ${ }^{9}$ which gave a date of $1245-1300 \mathrm{AD}(90.5 \%$ probability) or $1370-1385 \mathrm{AD}$ (4.9\% probability). ${ }^{10}$ The presence of this bone may indicate that the animal, or part of it, was cremated along with the deceased, or was

7 The artefacts have been dated on typological grounds, and considering analogous grave inventories. The chronology of artefacts from this period has so far not been corroborated by radiocarbon dating.

8 Determined by Laurynas Kurila, Institute of Lithuanian History, Vilnius.

9 Determination by Lembi Lõugas, Archaeological Research Collection, Tallinn University.

${ }^{10}$ Poz-73412, conventional $14 \mathrm{C}$ age: $720 \pm 30$ BP. Calibrated date: AD $1245-1300$ (90.5\% probability) or AD 1370-1385 (4.9\% probability). 

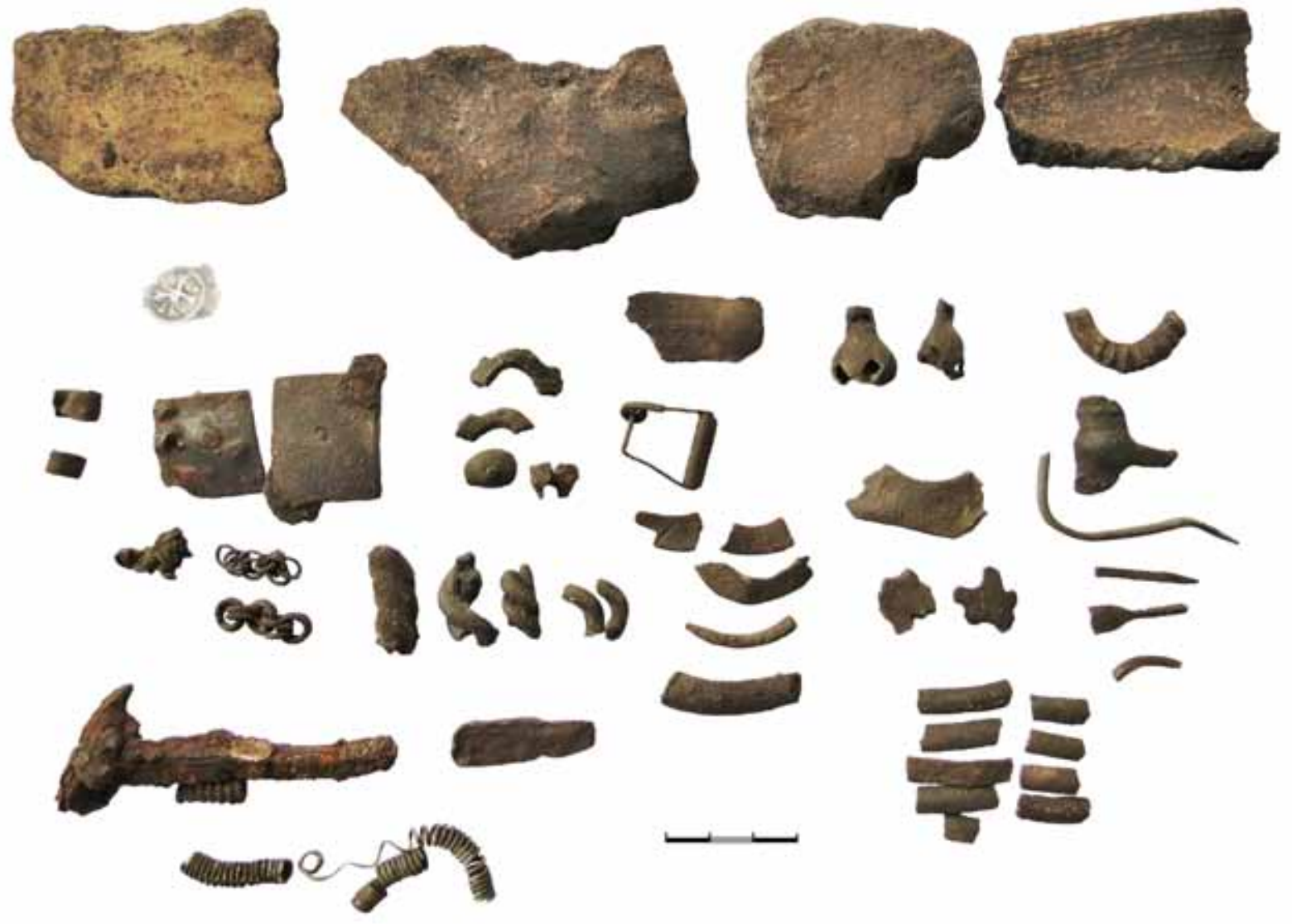

Figure 5. Finds from artefact concentration 5 (photograph by I. Donina).

part of the funeral feast. Burnt bone material from other Curonian cemeteries has not yet been analysed osteologically. The artefact finds (Fig. 5) include a silver bracteate of the Bishopric of Courland (variant 3$)^{11}$ and fragments of a brooch, a shoe buckle, neck-rings, bracelets, mounts, items of dress, etc, as well as a forged iron nail and a piece of a knife (?). In this grave, unlike in other Curonian burials from this period, the artefacts have been markedly deformed, all of them cut or hacked into small fragments only a few centimetres in size. Artefacts contemporary with this grave have been recovered at Darvdedži cemetery, located 12 kilometres from Lapini, where, in contrast to Lapinii, contemporaneous cremation and inhumation graves have been found, dated to the period from the second half of the 14th century to the second half of the 15th century.

In the disturbed area of the cemetery, a group of artefacts was uncovered (artefact concentration 4) that is believed to come from a single grave. Some of the artefacts had corroded together. These artefacts are approximately of the same date as the destroyed grave described above: the 14th

\footnotetext{
${ }^{11}$ Determined by the numismatist Tatjana Berga, Institute of Latvian History, Rìga.
}

or 15 th century. Only in contrast to this grave, the artefacts (Fig. 6) uncovered here (brooches, a bracelet, a ring, a shoe buckle, potsherds, etc) are minimally deformed, except for a cross-pendant, two arms of which are broken. A similar cross has been found in the Curonian cemetery of Popes Gugenieki, which had two arms broken in a similar manner. Such crosses also occur in earlier Curonian cemeteries. For example, at Raņku Kapenieki, which dates from the 11th or 12th century $\mathrm{AD}$, a cross with two broken arms was found in grave 2 .

These crosses could have been worn as symbols of the Christian faith, as status symbols, for aesthetic reasons, or as an amulet within the framework of the pre-Christian religious system. According to Adam of Bremen, around 1060, the Danes built a church in Courland and began to spread Christianity, but the Christian influence is hardly discernible. Practically throughout the Middle Ages, religious syncretism, the coexistence of the Christian and pagan traditions, persisted in Latvia. The viability of the pagan tradition is evidenced by the small number of Christian symbols (there are hardly any crosses from the southern part of the Curonian area) and the long con- 


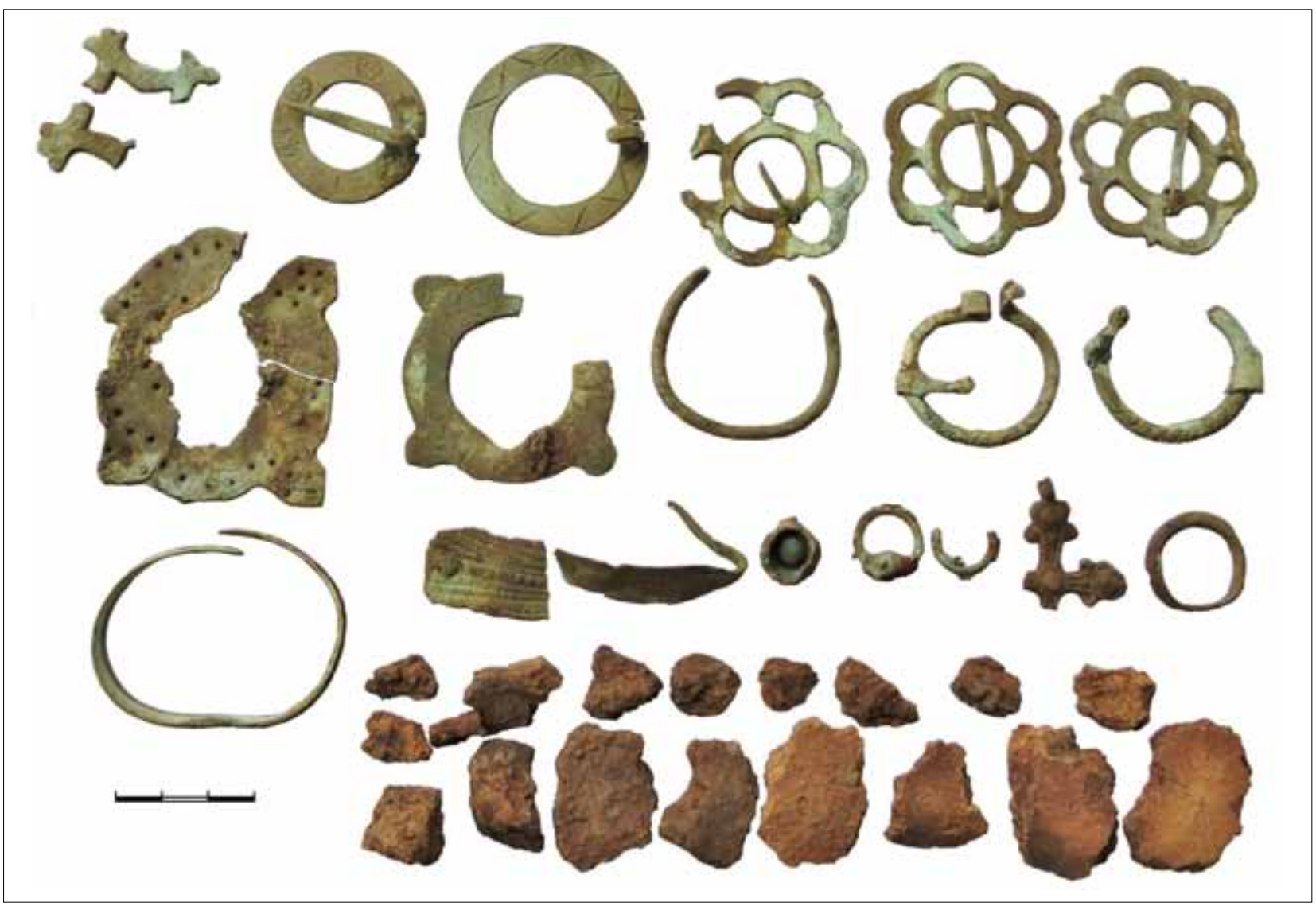

Figure 6. Finds from artefact concentration 4 (photograph by I. Donina).

tinuation of the practice of cremation (Asaris and Donina 2020).

Among the roots of a relocated tree stump, the original position of which is unknown, tightly packed artefacts (Fig. 7) were found, along with charcoal and a single tiny burnt bone fragment (artefact concentration 9). The artefacts (two plate brooches, a penannular brooch, ribbon bracelets represented by ten whole examples and 20 fragments, four coin-like pendants with chains, and bronze and iron wire, along with fused glass and iron beads, which may have been strung on a wire) had been placed in an approximately 15-centimetre-deep hole, above which a two to four-centimetre-thick charcoal layer was observed. The artefacts are thought to have come from the destroyed grave of a woman dating from the 13th or 14th century. Ribbon bracelets constitute a Curonian women's adornment, seven to 11 bracelets being worn on each arm in a specific order (Vaska 2017, p. 27).

The only weapons found as grave goods in this cemetery are iron axes, while tools are represented by a fire-steel. The ornaments are made of bronze; these include brooches, bracelets, finger-rings, a neck-ring, pendants (a cross, animal claw pendants and round pendants), items of dress (shoe buckles, loops, etc), a silver coin (bracteate of the
Bishopric of Courland), and sherds of hand-formed pottery. Most of the artefacts were placed on the pyre along with the deceased. They are burnt, fused and intentionally deformed: bent, broken and cut/hacked. The deceased were cremated at a high temperature, presumably above $800^{\circ} \mathrm{C}$, since the bones are calcined white and have become very fragile (Ellingham et al., 2015). The overall number of bones recovered from this burial site is very small. Presumably, the rest of the bones were either subjected to a certain ritual activity, for example, they were comminuted, or were not collected at all after cremation. In general, there is a common tendency at Curonian burial grounds from the late period in northern Courland to place very few burnt bones in the grave (as seen, for example, at Popes Guǵenieki and Popes Lazdas).

Indications of burning places are virtually absent at cremation cemeteries, and such a place could have been located some distance away from the graves. The mourners would have had to bring the cremated remains from the cremation site to the cemetery, which also provides an explanation for the small amount of bone found in the cemetery. Had the deceased been cremated in the cemetery itself, more bone could be expected, both quantitatively and qualitatively (Wickholm 2005, p. 33). Cremation places have rarely been discovered at Curonian cemeteries. One 


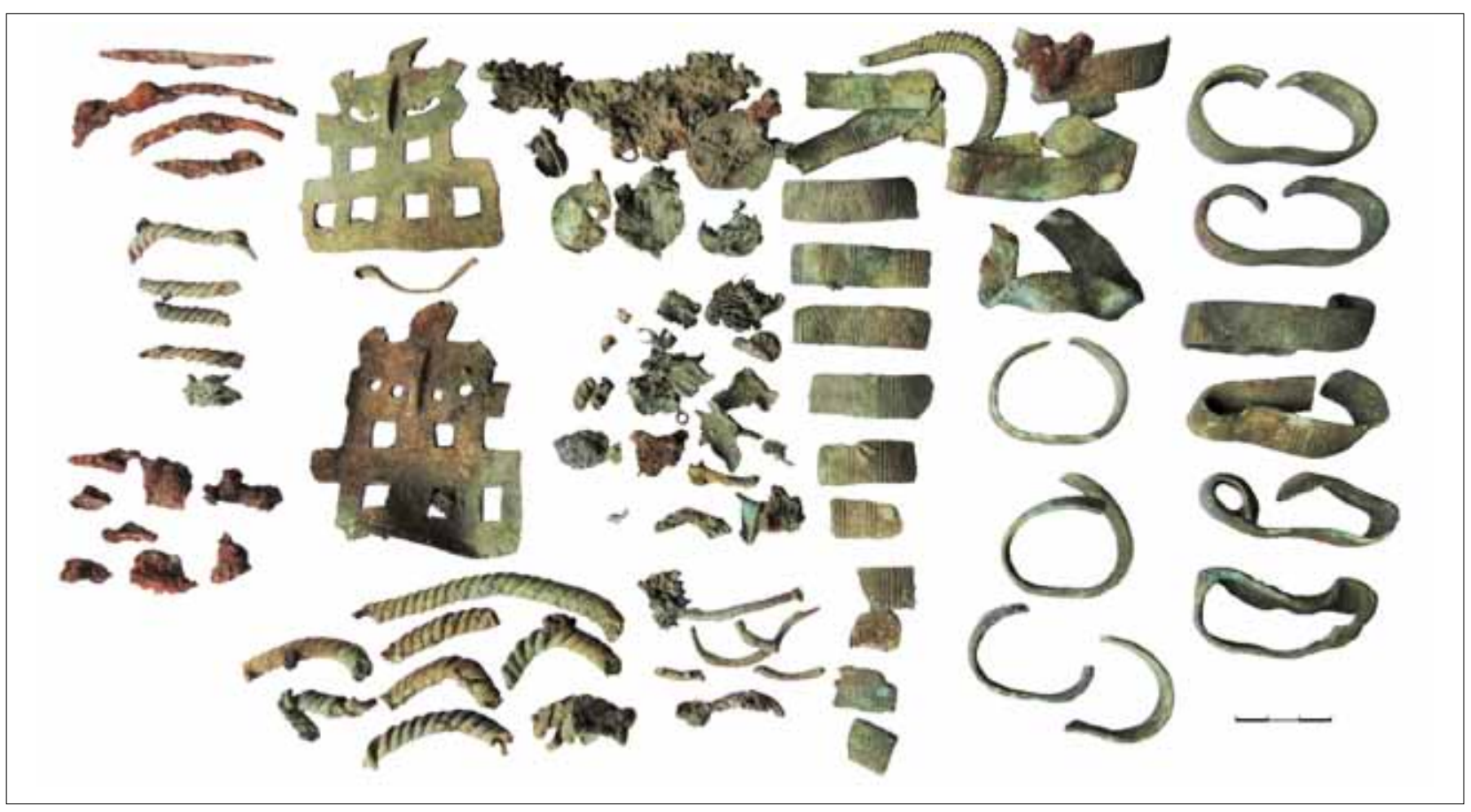

Figure 7. Finds from artefact concentration 9 (photograph by I. Donina).

such place may have existed in Palanga cemetery, Lithuania (Tautavičius 1963). After the cremation, the bones and artefacts would have been collected, possibly in a ceramic or organic container, and transported to the burial site. The lack of bone material at Lapini cemetery suggests that the bones were taken from the cremation site in accordance with particular principles, or were subjected to a particular ritual, such as being crushed after burning. The bone pieces recovered from Curonian cemeteries, especially from late cremation graves, are very small.

Most of the artefacts found in the cemetery had been intentionally damaged, either before or after the cremation. The same custom is known in Scandinavia, elsewhere in the Baltic States, and cremation burials in Finland, Estonia and the Karelian Peninsula. Pieces of a single artefact are sometimes scattered, and may be a few metres apart, but cemeteries may also contain clusters of artefacts indicating individual burials (Wickholm 2005, p. 33; Mägi 2015, p. 51; Kurila 2009, p. 8).

Palynological and palaeobotanical analyses

Two samples were taken from cremated burials for pollen and non-pollen palynomorph analysis. The combination of the two methods can provide information about the vegetation in the vicinity (local to regional vegetation signal), and point to particular burial processes (van Geel 2001; Kvavadze et al., 2010). One sample was obtained from the charcoal-rich layer within the coffin grave (sample 1), and another from the charcoal-rich layer within what is regarded as a classic cremation cemetery grave (sample 2). Samples for pollen and non-pollen palynomorph analysis of known volume $\left(4 \mathrm{~cm}^{3}\right)$ were processed using standard procedures. The samples were treated with $10 \% \mathrm{HCl}$, boiled in $10 \% \mathrm{KOH}$, and then acetolysed for five minutes using a standard acetolysis procedure combined with a concentrated HF treatment to remove inorganic matter (Berglund and Ralska-Jasiewiczowa 1986; Bennett and Willis 2001). Known quantities of Lycopodium spores were added to each sample, to allow the calculation of pollen concentrations (19584 Lycopodium per tablet, batch number 177745; Stockmarr 1971). All pollen and spores per sample were counted and identified to the lowest possible taxonomic level using the reference collection at the Department of Geology, Tallinn University of Technology, and published pollen keys (Fægri and Iverssen 1989). Nonpollen palynomorphs were recorded in the course of pollen analysis, and identified using the published literature listed in Miola (2012). In addition, phytoliths were identified in accordance with the International Code for Phytolith Nomenclature 2.0 (ICPT 2019). Percentages were estimated based on pollen sums, and the concentrations of microscopic remains per sample were estimated based on raw counts. Pollen and non-pollen palynomorphs were identified using a light microscope at magnifications of 200, 400 and $1000 \mu \mathrm{m}$ at the Department of Geology, Tallinn University of Technology, Estonia. Plotting the pollen 
and non-pollen palynomorph data was carried out using SigmaPlot software.

Only ten arboreal pollen taxa, eight non-arboreal taxa, and 16 types of non-pollen palynomorphs were identified (Figs. 8, 9). The spore-pollen analysis results indicate that at the time of the use of the cemetery, the surrounding area had mixed forests dominated by alder (Alnus), pine (Pinus), spruce (Picea), birch (Betula), elm (Ulmus) and grasses (Poaceae). Secondary species included hazel (Corylus), oak (Quercus), plants of the heather family (Ericaceae), and ferns (Polypodiaceae).

As the samples had been taken from a cremated burial, microscopic pieces of charcoal were not counted, since they would not provide valuable information for interpretation. At the same time, it should be noted that, in general, spores and pollen were identified as well as non-pollen material, which could provide additional environmental information. Microfossil preservation was poor, which is further evidenced by the low microfossil concentration values.

Considering that the samples come from a sandy charcoal-rich sediment, it is no surprise that conditions were not good for the preservation of organic remains such as pollen and spores. The majority of such remains cannot continuously exist under aerobic (oxygen-rich) conditions. Microorganisms (bacteria) and fungi consume organic compounds, leaving no trace of these remains. This assumption is supported by the presence of pine pollen filled with fungi. As a study by Shumilovskikh et al. (2015) has shown, saprotrophic and ectomycorrhizal fungi effectively use pollen cytoplasm as a crucial nutrient source for the fungi and their plant hosts in nutrient-limited environments. High atmospheric oxygen availability can boost ectomycorrhiza and saprotrophs (fungi), resulting in increased decomposition and nutrient availability, particularly from pollen.

In addition, fungal hyphae have been identified relating to soil processes. Soil fungi (Mycorrhiza) are found in different soils, but their presence usually decreases with the increasing depth of the soil. Fungi hyphae are fungal compounds and are considered the active phase of fungal formation. Generally, the highest concentration is seen in the part of the active soil where the roots of plants grow and the decomposition of plant residues and spores takes place. The pine pollen with ingrown fungi and the hyphae concentration could indicate the use of the surrounding topsoil to fill the grave, or confirm that the cremated remains were not buried, and were instead scattered over the ground or covered with a small amount of soil.

The surrounding landscape was not completely enclosed, most likely presenting a mosaic of grasses, hops (Humulus), hemp (Cannabis), nettle (Urtica), and sheep's sorrel
(Rumex acetosa). Fern spores and nettle pollen are found in shaded areas rich in specific nutrients (e.g. nitrogen). This pollen may indicate that economic activity could have occurred in the surroundings, not too far away. Of course, the possibility cannot be excluded that one or more of these plants could have been placed in the grave. However, in that case, the pollen concentration of these particular plants should be higher. In addition, since this is a cremation grave, the pollen should also be burnt, but the pollen found in the Lapini cemetery burial was not burnt or crushed, which makes it very improbable that the plants were placed in the cremation grave. Consequently, it should be concluded that the pollen is more likely to have been introduced at the time of the burial, when the grave was created. The tree pollen is also likely to be associated with the season when the grave was created (spring-autumn).

Microscopic plant remains indicate the presence of plants that have decomposed over the course of time. It should be noted that the high concentration of phytoliths and the abundance of grass pollen in the Lapini cemetery samples indicate the presence of grasses at this particular site. Phytoliths are microscopic silica (opal) structures produced in and between the cells of plants. They occur in almost all plant tissue types and across all living plant clades, either as individual cell infillings or as wholly silicified tissue sections, constituting up to $10 \%$ of plant dry weight (Piperno 2006; Rashid et al., 2019). Phytoliths are very significant in taxonomical studies, and their long-term preservation in sediments makes them a useful tool in the reconstruction of ancient plant communities and plant-human interactions. The phytoliths identified were with the entire margin, psilate surface and elongate (2-D) shape (according to the International Code for Phytolith Nomenclature 2.0, ICPT 2019). Identified elongated psilate phytoliths without well-defined ornaments or texture (Lisztes-Szabó et al., 2014) can be associated with Poaceae (grasses). In this particular situation, phytoliths can be associated with the soil surface, because plants live at the surface of the soil and after the death of the plant the organic matter decomposes, leaving phytoliths. The high concentration of phytoliths and the small quantity of identified microscopic residues once again point to an oxygen-rich environment characteristic of sandy soils. It is still unclear how phytoliths can be interpreted within a burial (charcoal-rich layer) setting. There are two possible explanations. One is that the cremated remains were not buried in the ground but were scattered over the surface. However, it is not known whether the remains were scattered on the surface of the soil at that time, or whether the top layer of soil had previously been removed. The other possible explanation could relate to a possible burial ritual, i.e. grass-type bedding material. It is too early to form a judgement, because further research is needed. 


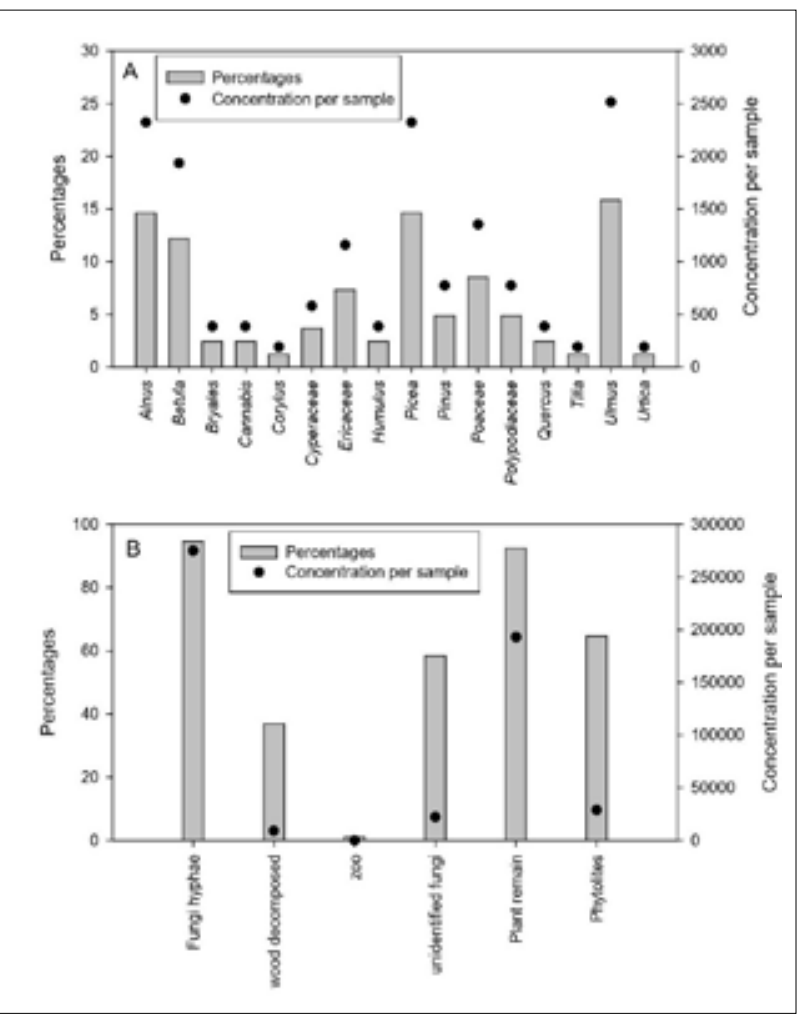

Figure 8. Diagram of pollen (A) and non-pollen palynomorphs (B) found in sample 1. Bars indicate percentages (\%), and dots indicate concentrations (microfossils per sample).

The fungal spores found during non-pollen analysis were small and morphologically difficult to identify. Most likely, these relate to certain plants whose pollen has been identified at Lapini cemetery. It is possible that their identification, which would indicate more specific environmental conditions, or plants with which they are associated, could be performed at some future point.

\section{Wood charcoal analysis}

A taxonomic study of wood charcoal was undertaken with the aim of characterising the wood used as fuel for cremation at Lapini. The charcoal fragments were split using a razor to obtain a fresh surface, and determined on the basis of anatomical features (Schweingruber 1982), using a LOMO MBS9 binocular microscope and a Leica $D M 4500 P$ microscope at magnification up to $\times 200$. Additionally, the curvature of the growth ring boundary was compared with a template, in order to obtain an estimate of the original diameter of the wood, with a division into five diameter classes following with the method of Ludemann and Nelle (2002). Forty-three charcoal fragments were determined, 14 of which were small fragments from two wet-sieved samples, the others being larger hand-collected samples.

Five tree genera are represented in this material (Table 1):

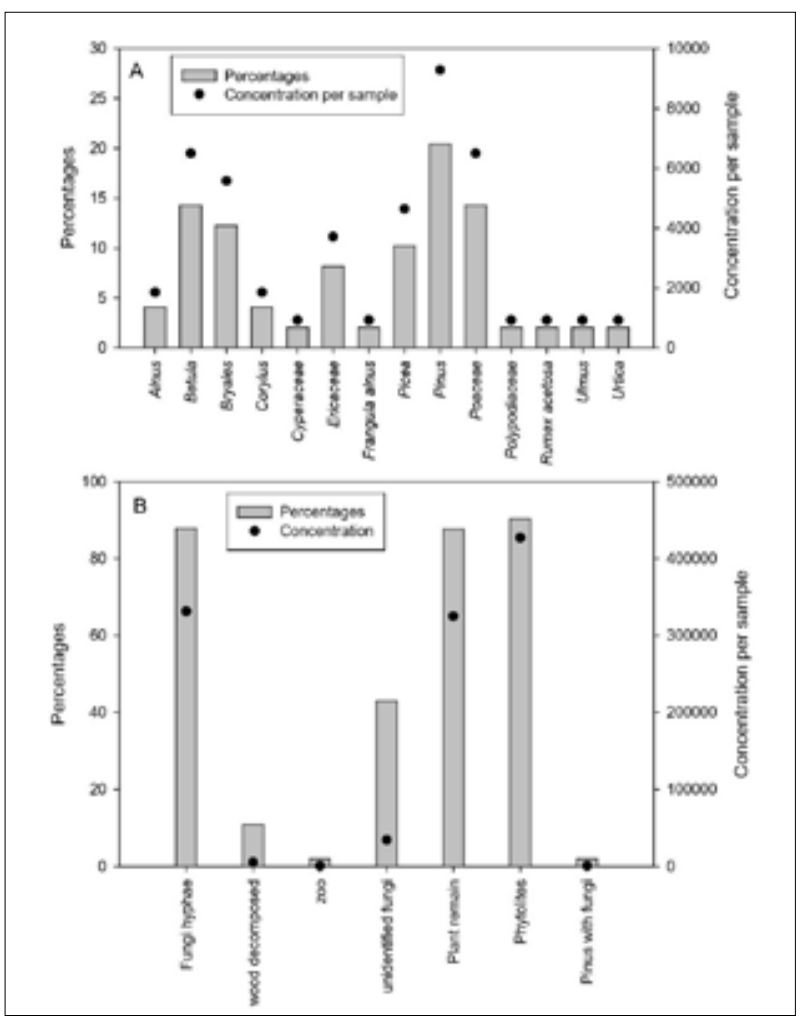

Figure 9. Diagram of pollen (A) and non-pollen palynomorphs (B) found in sample 2. Bars indicate percentages (\%), and dots stand for concentrations (microfossils per sample).

- $\quad$ pine (Pinus sp.), regarded as deriving from Scots pine, Pinus sylvestris;

- $\quad$ spruce (Picea sp.), regarded as Norway spruce, Picea abies;

- $\quad$ ash (Fraxinus sp.), regarded as European ash, Fraxinus excelsior;

- $\quad$ alder (Alnus sp.), either black alder, Alnus glutinosa, or grey alder, Alnus incana;

- $\quad$ birch (Betula sp.), either silver birch, Betula pendula, or downy birch, Betula pubescens.

In two cases (very small friable pieces), a distinction could not be made between pine and spruce.

The diameter estimates indicate that the charcoal derives primarily from large-diameter material (trunks or large branches). The few pine charcoal fragments classed as two to three centimetres and three to five centimetres could originate either from smaller branches or from the inner parts of charred large-diameter material.

The determined charcoal fragments are from seven different excavation areas, and so the range of taxa may be expected to reflect the general range of woods used for cremation at this burial site. As is shown in Table 1, pine is dominant, with small amounts of ash, spruce, alder 
Table 1. Wood taxa and diameter classes determined in the charcoal analysis.

\begin{tabular}{|c|c|c|c|c|c|c|c|}
\hline \multirow[b]{2}{*}{ Taxon } & \multirow{2}{*}{$\begin{array}{c}\text { No. of } \\
\text { fragments }\end{array}$} & \multicolumn{6}{|c|}{ Diameter class (cm) } \\
\hline & & $<2$ & $2-3$ & $3-5$ & $5-10$ & $>10$ & Indet. \\
\hline Pine (Pinus) & 28 & - & 2 & 3 & - & 11 & 12 \\
\hline Spruce (Picea) & 3 & - & - & - & - & 2 & 1 \\
\hline Ash (Fraxinus) & 7 & - & - & - & - & 4 & 3 \\
\hline Alder (Alnus) & 2 & - & - & - & - & 1 & 1 \\
\hline Birch (Betula) & 1 & - & - & - & - & - & 1 \\
\hline Pine/spruce (Pinus/Picea) & 2 & - & - & - & - & - & 2 \\
\hline Total & 43 & & 2 & 3 & & 18 & 20 \\
\hline
\end{tabular}

and birch. It should be noted that two of the pine charcoal fragments from area 17 were incompletely charred (partially dark brown rather than black), and these most probably relate to recent burning events. Considering that a proportion of the samples were recovered from a shallow depth below the surface of the ground, there is a possibility that the other charcoal fragments, too, could include some modern material (on the other hand, none of the five ${ }^{14} \mathrm{C}$-dated charcoal fragments gave a recent date).

Considering that silver birch is one of the main pioneer species that colonises abandoned clearings and other open sites, and is also known as good-quality firewood, the low representation of birch charcoal (a single fragment) might be seen as an indication that the fuel collected for the funeral pyres did not come from an area that was intensively used for clearance farming.

In the context of this site, the alder charcoal is more likely to represent black alder rather than grey alder, because there is an extensive area of wet terrain immediately to the east, where black alder grows today. Pine and spruce occur commonly on the sandy soils in this tract of forest at the present time, while ash may be found on the damp, nutrient-rich soils along the edge of the nearby Sārnate Bog. Pine could have been used as wood for cremation, both because the body could be burnt relatively quickly due to the resin contained in the wood, and because of the specific aroma emitted during the burning process, which helps suppress the smell of the burning corpse (Deforce and Haneca 2012). Availability in the area could also be a strong factor.

An intriguing aspect is the use of ash for burial purposes (as is indicated by charcoal finds), whereas there is a lack of ash pollen. Either the ash was supplied for cremation from elsewhere, or, a more likely scenario, ash pollen has not been preserved under these circumstances.

All the taxa identified at Lapini are regarded as good firewood, but of course, the selection of wood for cremation purposes may have been influenced not only by considerations relating to the availability and fuel properties of different wood species, but also by beliefs and customs connected with the practice of cremation. That the Curonians did indeed attach a special importance to the choice of wood for cremation is suggested by the account given of pagan Curonian cremation practices by the French traveller Guillebert de Lannoy, cited above, where he states that exclusively oak was used for this purpose (Šturms 1938, p. 93). However, in the sandy plains of the coastal belt, where Lapini is located, oak would probably not have been available in sufficient quantity for the needs of cremation. To the authors' knowledge, charcoal analysis has so far not been undertaken on samples from other Late Iron Age/ Medieval Curonian cremation cemeteries, and so we do not yet have a broader picture of practices in that period.

Charcoal has been analysed from a 2nd to 5th-century Curonian cemetery at Mazkatuži, located much further south, close to the present Lithuanian border. In this case, pine, spruce, alder, aspen, birch, elm and oak were identified, with a predominance of the latter. Evidently, oak was available in that area at the time in sufficient quantity to be used in burial rites, which has been taken as confirming that broadleaf forests were formerly more extensive in Latvia than in the 20th century (Kupffer 1928).

Charcoal has also been determined from the 9th/10thcentury Scandinavian cremation cemetery at Lapsas, near Kuldiga, in the central part of the Courland Peninsula: in this case, alder and pine were used (Lūsēns 2016, p. 59).

\section{Landscape and social context}

Curonian cemeteries are usually located on small elevations of glacial till, or on hillocks near water, rivers, streams or lakes. The Lapini burial ground is located about two kilometres from the Baltic Sea on a sandy rise. Unlike most other Curonian cemeteries, Lapini is located on an elevation delimited by a boggy depression on the east side (the northern part of Sārnate Mire). In the low-lying eastern part of the site, concentric brown-and-white rings were visible in the sandy soil close to groundwater level. These patterns, known in geology as Liesegang bands, may in this context be attributed to the migration of iron or 


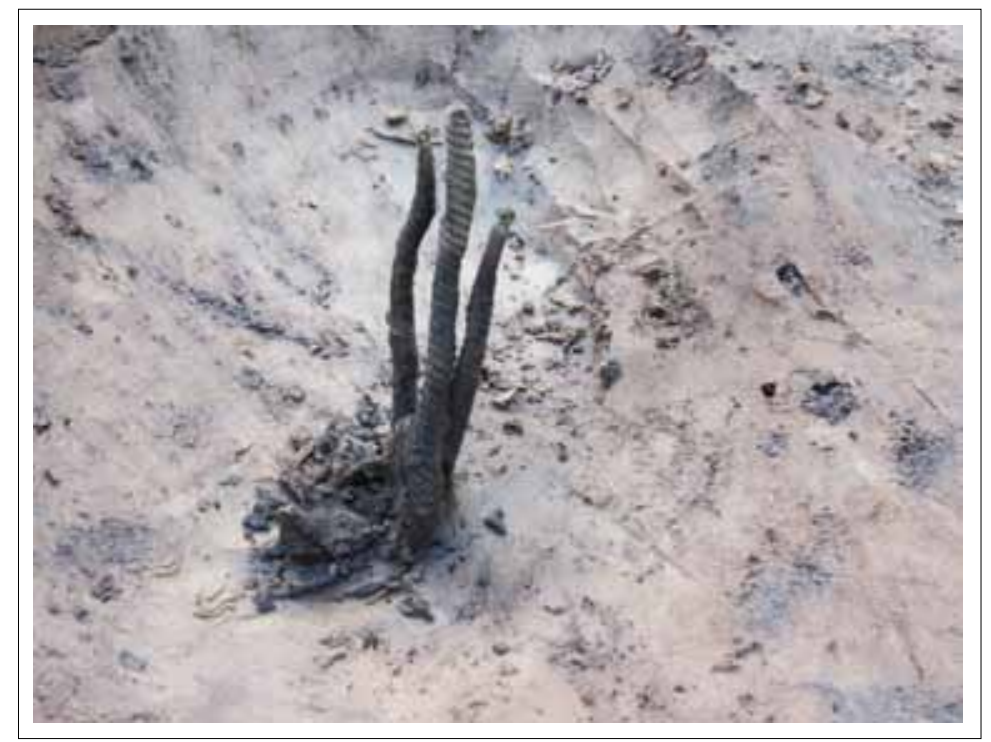

Figure 10. Finds from Lapini cemetery in situ. Fragments of neck-rings pushed vertically into the ground (photograph by I. Donina).

manganese minerals, as a result of intensive groundwater flow. ${ }^{12}$ It could be that at the time of the burials, this part of the site may have been a damp hollow with groundwater outflow. A cluster of artefacts was found at one particular location: broken and straightened neck-ring fragments, a straightened ring, chain dividers, etc (Fig. 10). These had been pushed vertically into the ground at a place where a spring might have emerged, as is indicated by the Liesegang bands surrounding the artefacts. It is possible that the drainage of the nearby bog, initiated in the 1930s (Nomals 1942, pp. 14-15), has contributed to bringing about drier conditions at this location.

Artefacts pushed vertically into the ground at the location of a spring have so far been found only at Lapini cemetery. Similarities can be identified with other Curonian cemeteries that contain vertical artefacts, such as Gugenieki, where such finds include two knives, a bracelet, a fire-steel and a finger-ring, as well as a burnt bone (Doniņa 2018, pp. 24-25). The case of Lake Vilkmuiža also remains uncertain: it is not clear whether the cremated remains were scattered in water, washed into the lake as a result of a landslide, or buried in a wet area (Donina 2016), as may have been the case at Lapini. Curonian artefacts have also been found in other swampy locations. For example, 20 Curonian artefacts from the 11th and 12th centuries, and animal bones, have been found at Krotes Brūveri spring (Urtāns 2004, pp. 81-85), and typical Curonian ribbon bracelets have been found in Kazdangas Bāzēni bog (Šturms 1935, p. 24). However, these are not cemeteryrelated finds; rather, they are offerings in wet and swampy

\footnotetext{
${ }^{12}$ Personal communication from Valdis Segliņ̧̌, professor of applied geology, University of Latvia, 01.07.2013.
}

places. Although A. Bliujienè associates the Vilkmuiža finds with such an offering site, the artefacts themselves and the signs of deformation they display correspond with finds from Curonian cemeteries (Bliujiene 2010, pp. 142143; Doniņa 2016).

An important feature of the Curonian cemeteries is that they are not visible above the ground, and there are no other above-ground features. For this reason, they are usually lost in the landscape. Whether this was deliberate is unknown. These cemeteries are usually found accidentally during agricultural or forestry work. Often, Curonian cremation graves, especially later ones, ${ }^{13}$ are relatively shallow (20 to 40 centimetres deep on average), or else the remains were not actually buried, and so they have generally been disturbed by land use. Typically, individual finds from burials occur over large areas, and cannot be reliably associated with specific burials. Occasionally, disturbed finds from a later date have been re-deposited within the boundaries of earlier burial pits, and vice versa (Muižnieks 2008, p. 38). In the case of Lapiņi cemetery, it was found during the construction of a forest road, when it was partially destroyed.

Curonian cemeteries, like cremation cemeteries in Finland, Estonia and Karelia, pose similar questions. What did the cemeteries look like during their use? Were they free of grass and turf, and was the black sooty soil visible to everyone, including grave-robbers? Archaeological excavations show that a cemetery grows over with grass only a few months after excavation, very soon rendering it invisible. Cemeteries have always led to debate as

\footnotetext{
${ }^{13}$ In Latvian archaeology, the term 'late cremation graves' refers to burials from the 13th to the 15th century.
} 


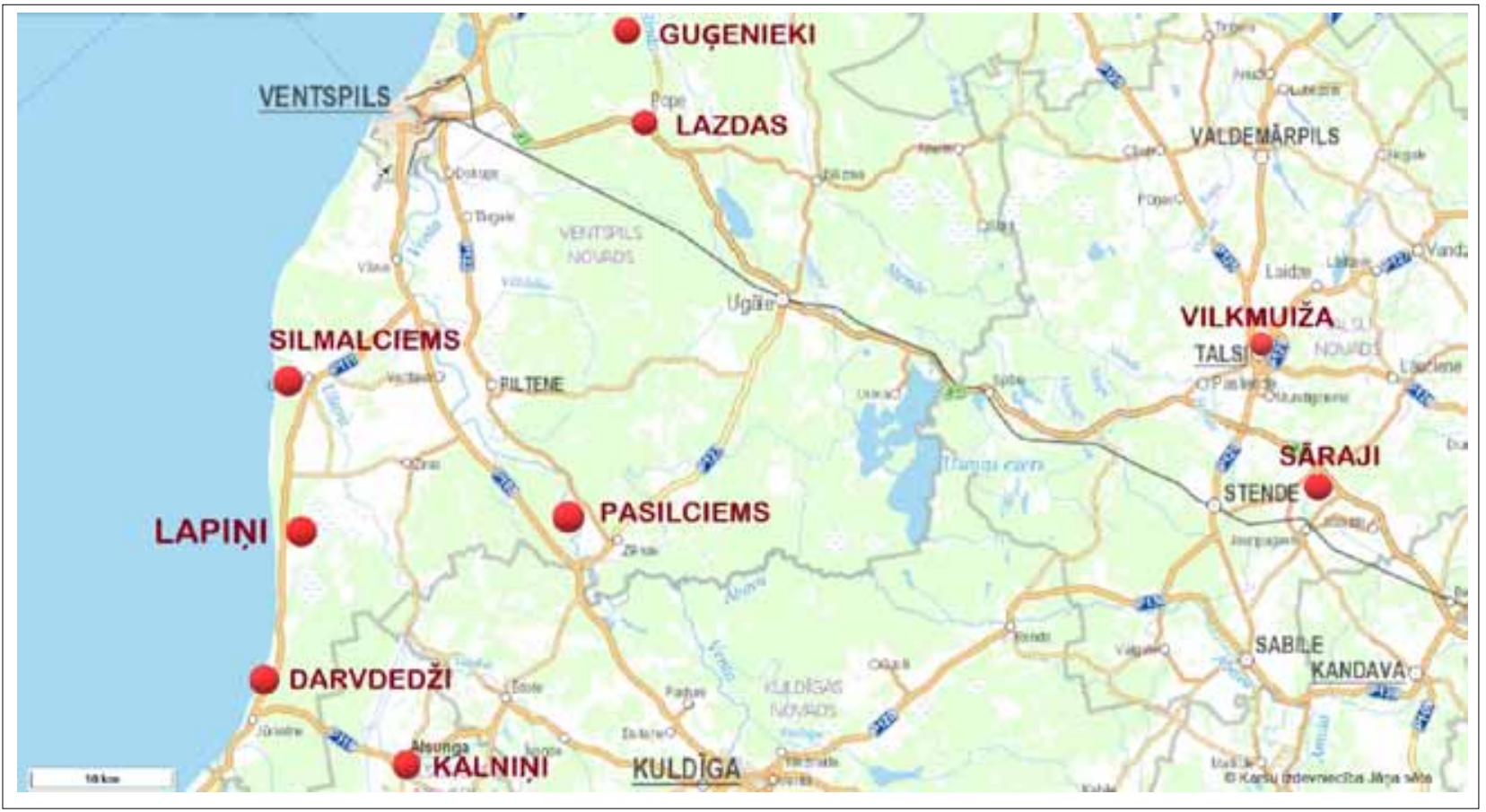

Figure 11. Map showing the Curonian cremation cemeteries discussed in the text.

to whether graves were originally marked with stones or trees to distinguish them from one another, and whether cemeteries were delimited on the ground, for example, by a fence. Unfortunately, such lightweight structures leave no trace. This would have made the burial place more visible in the landscape, and would have made it easier for people to distinguish the cemetery from the surrounding forest (Wickholm 2005, p. 33).

Nowadays, Lapini cemetery is located in a forest about two kilometres north of the village of Särnate, in a 1.5 to three-kilometre-wide naturally enclosed area, with the Baltic Sea on one side and the northern tract of Sārnate Mire on the other. No settlement relating to the cemetery has so far been found. The nearest settlements to Lapini cemetery mentioned in the 1230 Documents on the Division of Courland are Užava (Osua), Sārnate (Sarnitus) and Vendzavas (Venelis), kiligunds of Saggar land (Švābe 1938, p. 68). The cemetery is located about two kilometres from the present village of Sārnate, about ten kilometres from the village of Užava, and about three kilometres from the village of Vendzavas. As the region around Lapini burial ground forms part of the Baltic Ice Lake sandy plain, the terrain does not provide a suitable site for a hillfort. Since the nearest hillfort is 20 kilometres from the cemetery, it can be assumed that the deceased buried at Lapini came from the vicinity of the village of Sārnate. In the vicinity of Užava, there is the Silmalciems cemetery, which was in use contemporaneously with Lapini cemetery (second half of the 12 th century up to the first half of the 14th century, and second half of the 15th century up to the Modern Era) (Fig. 11). Here, in contrast to Lapini, after a chronological break, burials continued from the Middle Ages right up to the present day. Silmalciems burial ground is located about eight kilometres from Lapiņi, and the cemetery of Jūrkalnes Darvedži is 12 kilometres away ${ }^{14}$ (Fig. 11). The cremation graves and inhumations here are from the same period as Lapini cemetery, dated to the interval from the second half of the 14th to the second half of the 15th century. Twelve of the excavated burials were inhumations. A double burial of a female and a male (child?) may be numbered among late cremation graves (Muižnieks 2016, p. 258). The cemetery at Zlēku Pasilciems is located about 20 kilometres from Lapini. More than 100 burials have been excavated there (Griciuvienè 2009, p. 450). ${ }^{15}$ Burials took place there from the second half of the 11th century, when cremation was practised, right up to the 15th century. The cemetery was most used in the 12th and 13th centuries. Alongside cremation, starting from the 14th century, there was a shift to burial in inhumation graves (Tomsons 2018, pp. 215-216).

${ }^{14}$ At the time of excavation in 1936, the cemetery had already been partially eroded by the Baltic Sea.

${ }^{15}$ Excavations at Pasilciems cemetery took place in 1895, 1897, 1932 (led by Vladimir Sizov, Nikolai Brandenburg and Eduards Šturms). Most of the material is held in two Russian museums: the State Hermitage Museum in St Petersburg, and the State History Museum in Moscow. Most of the finds are from the end of the 19th century, completely lacking documentation in the modern sense. Because of this, it is not possible to reconstruct individual burial assemblages, or obtain an idea of the layout of the cemetery (Tomsons 2018, pp. 215-216). 


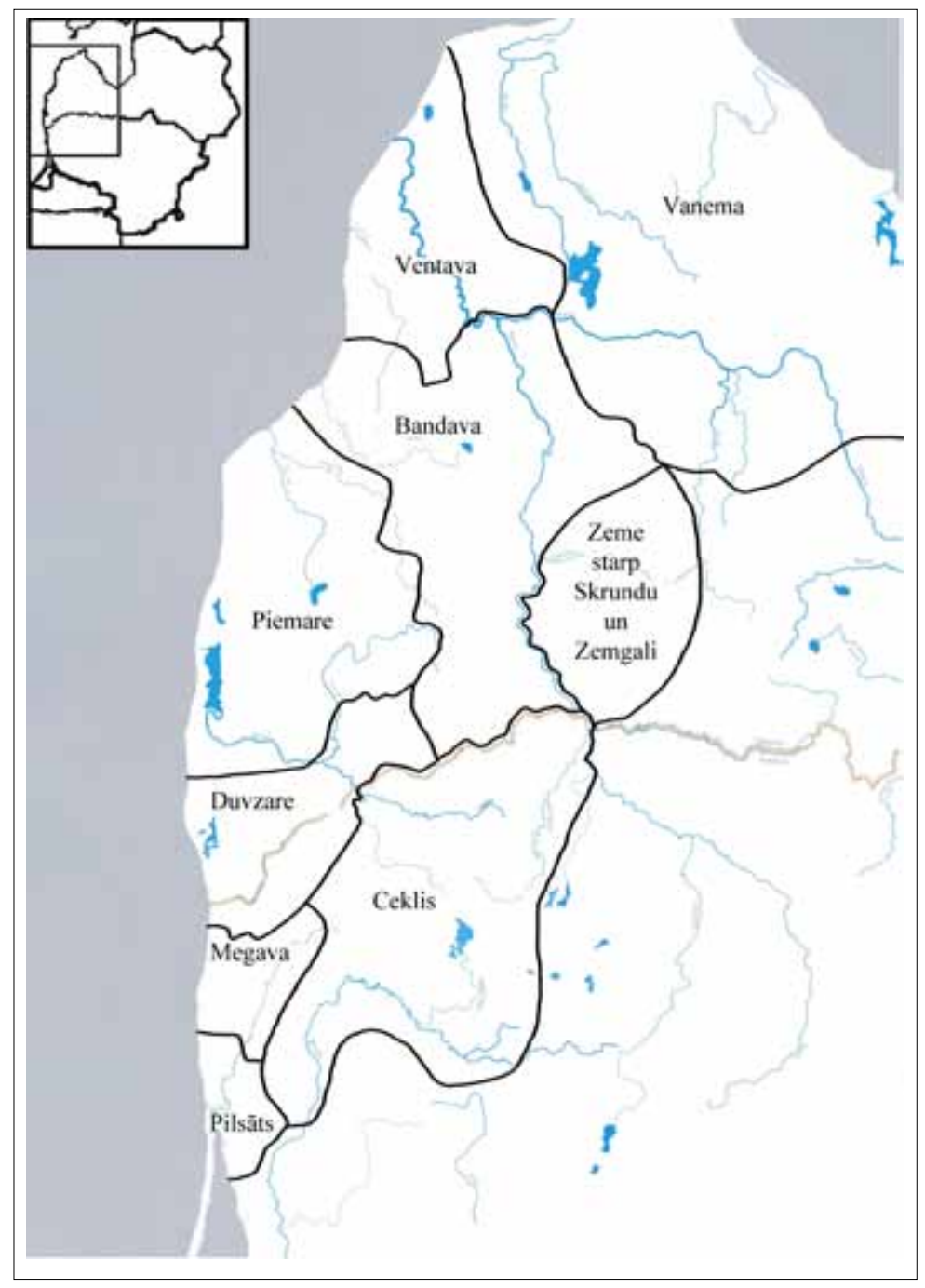

Figure 12. Map of the Curonian lands.

Lapini cemetery was located in Ventava, ${ }^{16}$ one of the nine Curonian lands (terra, land) mentioned in the Book on the Division of Curonia of $1253,{ }^{17}$ and is believed to have been on the periphery of this land (Fig. 12). The centre of Ventava is thought to have been located in the vicinity of Zlēkas, where both a hillfort and a higher concentration of cemeteries have been identified (Mugurēvičs 1999, p. 62). This is considered to have been a strategically located centre of the region, near the Venta waterway. The coin deposit found in Piltene, dating from 1251, and other coin finds in the region, clearly mark the route from the sea along the River Venta. The Venta waterway in Courland started at the mouth of the river, and was accessible to seagoing ships up to the waterfall at Kuldiga, which was an

\footnotetext{
${ }^{16}$ In written sources the lower Venta area is initially referred to as Saggare (1230).

${ }^{17}$ The Curonian lands: Vanema, Ventava, Bandava, Piemare, Duvzare, Ceklis, Pilsāts, Megava, as well as the territory between Skrunda and Semigallia.
}

important intersection of land routes. The Venta waterway was already well used by the Vikings during the 9th and 11 th centuries. Coin finds indicate that northern Courland had significant trade centres, and one of the most important trade routes in Latvia (Berga 2014, p. 21). Zlēku Pasilciems cemetery is located by the lower course of the Venta, on its left bank. The cemetery belongs to Curonian culture. This cemetery has produced a helmet (one of five found in Curonian territory) and a shirt of mail armour (Atgāzis 2019, p. 168), a large number of weapons, including swords, and scales and weights. Other grave goods include 11 coin pendants with bronze loops. The large number of weapons found in northern Courland indicates a highly militarised society (military retinues) in the 12th and 13th centuries, and even the flourishing of such a lifestyle. It is possible that after the decline in activity among the southern Curonians, the Curonians of northern Courland played a leading role in both military and trade contacts with Scandinavia and the north German cities from the end of the 11th to the middle of the 13th century. And it was they who were most concerned about German ac- 
tivities at the mouth of the Daugava in the late 12th and early 13th century. The rise of the military retinue in the northern part of Courland continued in the 12th and possibly also the 13 th century.

It is possible that the Curonian movement into northern Courland did not occur peacefully, and so they needed to retain militarised formations for a longer period of time. Even after the 13th century, when the Curonian people formally became subjects of the Livonian Order, the inhabitants of Livonia did not immediately lose their personal freedom. This happened in the period up to the early 16th century (Asaris 1996, pp. 38-42; Asaris and Donina, 2020). It included the freedom to use and carry weapons for personal protection. Written sources from the 14th century indicate that certain wealthy peasants owned weapons. This may be confirmed by finds of swords from the 14th and 15th centuries at Talsu Vilkmuiža and Zlēku Pasilciems (Tomsons 2018, p. 217).

It is probable that the Curonians, penetrating into the area inhabited by the Baltic Finns (Vends), first moved along the River Venta, and then up the River Abava, to more fertile and previously cultivated lands (Asaris 1996, p. 41), and strategically important routes. After that, they occupied less populated, less fertile and less important regions. Compared to other Curonian cemeteries in inland areas, such as Zlēkas Pasilciems and Lībagu Sāraji, the Lapiṇi burial ground is located in a low-fertility region, on the sandy plain of the former Baltic Ice Lake. Curonian burials give a poor reflection of the professional occupation of the deceased (Šnē 2002, p. 142), so it is not possible to determine whether there are occupational differences between the Curonians of the inland and coastal areas. It can be assumed that in Curonian society, the main livelihoods included agriculture and livestock farming. However, no burials at Lapini have so far been found with scythes, as have been found in other Curonian cremation graves from this period (Lībagu Sāraji). In the case of Lapinii, fishing might also have been important, given the proximity to the sea and the barren soils of the dune belt. The graves at Lapini cemetery, unlike those of other Curonian cemeteries of this period in northern Courland (Lìbagu Sāraji, Talsu Vilkmuiža lake, Zlēku Pasilciems) (Fig. 11), do not present visible features (rich burials with weapons, trading equipment, etc) that would point to the existence of a militarised society (with a professional military retinue). This suggests that the area was located in a less important territory, where no active confrontation with the Baltic Finns (Vends) took place.

When the lower reaches of the River Venta came under the Crusaders, Ventava was divided between the Livonian Order and the Bishopric of Courland. Two thirds of Ventava, the entire coast (including the area around Lapini), fell to the Order. At the end of the 13th century, the Order built a castle at the mouth of the River Venta, and established a harbour that controlled the traffic on the Venta. The rest of Ventava, the land on either side of the Venta as far as the Abava (including Zlēkas), was under the control of the diocese (Mugurēvičs 1999, p. 63).

\section{Conclusions}

Lapini is a cemetery with the last Curonian cremation burials from the 13th to the 15th centuries. Burials at this cemetery took place from the 12th to the 14th or 15th century. It could have occupied an area of approximately 2,000 to 3,000 square metres. Cremated remains occur within this area in some cases only five centimetres below the turf. Burnt bone, artefacts, pottery and charcoal are scattered over a large area. In individual cases, the cremated remains of the dead have been buried in small pits, or in one case, placed in a coffin in a rectangular grave.

A significant feature of these cemeteries is that they are not visible above the ground, which makes them disappear into the landscape. The absence of above-ground structures, and the flat landscape, make the Curonian cemeteries almost invisible, although they are usually located on slopes or on small elevations in the glacial till. Lapini cemetery is on a low sandy ridge at the edge of the northern tract of Sārnate Mire. Drainage work has been undertaken in the vicinity of the mire, and nowadays the eastern part of the burial ground is in a damp hollow. The burial ground is located on the sandy plain of the former Baltic Ice Lake.

Taxonomic analysis of charcoal samples from different parts of Lapini cemetery indicates that pine, as well as ash, spruce, alder and birch, was used as firewood.

So far, no settlement has been found that might relate to the cemetery. Presumably, it could be near the presentday village of Sārnate. This village, approximately two kilometres from the cemetery, was mentioned in an agreement in 1230 as Sarnitus. Lapini cemetery is believed to have served as a burial place for one small community or household. Curonian cremation graves give a poor reflection of the occupations of the deceased. There are no discernible features at Lapini cemetery that would indicate the existence of a militarised society (a professional military retinue). Such indications can be found at other Curonian burial grounds.

\section{Acknowledgements}

The research on which this paper is based was carried out as part of the projects 'People in a Dynamic Landscape: Tracing the Biography of Latvia's Sandy Coastal Belt' (LZP-2018/1-0171) and 'Towards a New Prehistory of 
Latvia: Tracing Long-Term Change from Habitations and Burials' (ZD2015/6239).

Radiocarbon dating of archaeological samples was funded by the State Culture Capital Foundation.

\section{References}

\section{Manuscripts}

Hudson, A.W., 2013. Cremation: A Case Study. Report prepared for Dr. Cheryl Johnston, Department of Anthropology. Western Carolina University, Cullowhee, NC (unpublished report).

Tautavičius, A., 1963. Palangos senkapio $1962 \mathrm{~m}$. rugséjo 14 spalio 17 d. vykdytu kasinejimu ataskaita. Unpublished excavations report. Institute of Lithuanian Historty, Archive, corpus 1, file No 182.

Plankājs, E., 2017. Vendi Latvijas teritorijā vēlajā dzelzs laikmetā un viduslaiku sākumā. Thesis (MA). University of Latvia.

\section{Literature}

Asaris, J., 1996. Par kuršu izplatîbu Ziemeḷkurzemē 11.-13. gs. Arheologija un etnogrāfija, 18, 38-42.

Asaris J. and Doniņa, I., 2020 (in print). Kurši 12.-13. gadsimtā: sabiedrība, kultūra un reliǵija. In: Vara, zeme un sabiedrība: politiskās un sociālās transformācijas Austrumbaltijā 12. un 13. gadsimtā.

Asaris, J., Muižnieks, V., Radinš̌, A., Virse, I. and Žeiere, I., 2008. Kurši senatnē / Couronians in Antiquity. Rīga: Latvijas Nacionālais vēstures muzejs.

Atgāzis, M., 2019. Tuvcīnas ieroči Latvijā 10.-13. gadsimts. Rīga: Latvijas vēstures institūta apgāds.

Bennett, K.D. and Willis, K.J., 2001. Pollen. In: J.P. Smol, H.J.B. Birks, W.M. Last, eds. Tracking Environmental Change Using Lake Sediments, Terrestrial, Algal, and Siliceous Indicators, vol. 3. Dordrecht-London: Kluwer Academic Publisher, 5-32.

Berga, T., 2014. Piltenes depozìts: naudas apgrozība Kurzemē 13. gadsimta. The Piltene hoard: coinage circulation in Courland in the 13th century. Riga: Zinātne.

Bērziņš, V. and Doniņa, I., 2014. Izrakumi Lapiṇu mezolīta apmetnē un kuršu ugunskapos 2012. gadā. In: J. Urtāns, I. Virse, eds. Arheologu pētījumi Latvijā 2012. un 2013. gadā. Riga: Nordik, 9-13.

Bērziṇš, V., Doniṇa and I., Kalniṇš, M., 2016. Fosfātu kartēšana un izrakumi Lapiṇu mezolīta apmetnē un kuršu ugunskapos. In: J. Urtāns, I. Virse, eds. Arheologu pētījumi Latvijā 2014. un 2015. gadā. Riga: Nordik, 9-15.

Bliujienè, A., 2010. The Bog offerings of the Balts: 'I give in order to get back. Archaeologia Baltica, 14, 136-165.

Bliujiene, A. 2016. The Curonians of the Lithuanian Coast. In: G. Zabiela, Z. Baubonis, E. Marcinkevičiūte, eds. A Hundred Years of Archaeological Discoveries in Lithuania. Vilnius: Lietuvos archeologijos draugija, 268-285.

Deforce, K. and Haneca, K., 2012. Ashes to ashes. Fuelwood selection in Roman cremation rituals in northern Gaul. Journal of Archaeological Sciences, 39 (5), 1338-1348.

Doniņa, I., 2016. Mirušo apbedī̌̌ana ūdenī, mīts vai īstenība? In: Z. Konošonoka, ed. Talsu novada muzeja raksti. Talsu novada muzejs, 2, 7-18.

Doniņa, I., 2018. Arheoloğiskie pētijumi Guğenieku senkapos un Popes pilskalnā 2017. gadā. In: J. Urtāns, I. Virse, eds. Arheologu pētījumi Latvijā 2016. un 2017. gadā. Riga:Latvijas Universitātes Latvijas vēstures institūts, 23-28.
Ellingham, S.T.D., Thompson, T.J.U., Islam, M. and Taylor, G., 2015. Estimating temperature exposure of burnt bone - A methodological review. Science \& Justice, 55 (3), 181-188.

Fæegri, K. and Iversen, J., 1989. Textbook of Pollen Analysis. New York: Wiley.

van Geel, B., 2001. Non-pollen palynomorphs. In: J.P. Smol, H.J.B. Birks, W.M. Last, eds. Tracking Environmental Change Using Lake Sediments, Terrestrial, Algal, and Siliceous Indicators, vol. 3. Dordrecht-London: Kluwer Academic Publisher, 99-120.

Griciuvienè E. (ed.), 2009. Kuršiai: genties kultūra laidosenos duomenimis: Baltu archeologijos paroda: katalogas / The Curonians: tribe culture according to the burial data: Baltic archeological exhibition: catalogue. Vilnius: Lietuvos nacionalinis muziejus, Latvijas Nacionālais vēstures muzejs.

International Committee for Phytolith Taxonomy (ICPT), 2019. International Code for Phytolith Nomenclature (ICPN) 2.0. Annals of Botany, 124, 189-199.

Indriķa hronika. 1993. No latīņu valodas tulkojis Ā. Feldhūns; $\overline{\mathrm{E}}$. Mugurēviča priekšvārds un komentāri. Rīga: Zinātne.

Kupffer, K.R., 1928. Organische Reste aus vorgeschichtlichen Grabstätten in Kurland. Anhang A. In: Wahle, E. Die Ausgrabungen in Rutzau und Bauske (Archaiologijas Raksti I, 2), 65-73.

Kurila, L.V., 2009. The Social Organisation in East Lithuania in the $3^{\text {rd }} 12^{\text {th }}$ Centuries (on the Basis of the Mortuary Record). Summary of doctoral dissertation. Vilnius University.

Kvavadze, E., Narimanishvili, G., Bitadze, L., 2010. Fibres of Linum (flax), Gossypium (cotton) and animal wool as non-pollen palynomorphs in the late Bronze Age burials of Saphar-Kharaba, southern Georgia. Vegetation History and Archaeobotany, 19, 479-494.

Lemmers, S.A.M., 2012. Burned culture: osteological research into Urnfield cremation technology and ritual in the South of the Netherlands. LUNULA. Archaeologia protohistorica, 20, 81-88.

Lisztes-Szabó, Z., Kovács, S. and Petö, Á., 2014. Phytolith analysis of Poa pratensis (Poaceae) leaves. Turkish Journal of Botany, $38,851-863$.

Ludemann, T. and Nelle, O., 2002. Die Wälder am Schauinsland und ihre Nutzung durch Bergbau und Köhlerei (Schriftenreihe Freiburger Forstliche Forschung, t. 15). Freiburg: Forstwissenschaftliche Fakultät der Universität Freiburg und Forstliche Versuchs- und Forschungsanstalt Baden-Württemberg.

Lūsēns, M., 2000. Arheologiskie pētījumi Popes pagasta Lazdu senkapos. In: I. Stašulāne, ed. Arheologu pētījumi Latvijā 1998. un 1999. gadā. Rìga: Latvijas vēstures institūta apgāds, $128-132$.

Lūsēns, M., 2016. Jauns skandināvu kapulauks Kurzemē. In: J. Urtāns, I.L. Virse, eds. Arheologu pētījumi Latvijā 2014. un 2015. gadā. Rīga: Nordik, 58-62.

Mägi, M., 2002. At the Crossroads of Space and Time. Graves, Changing Society and Ideology on Saaremaa (Ösel), 9th-13th centuries $A D$. CCC papers: 6. Gotland University College, Centre for Baltic Studies; Institute of History, Department of Archaeology.

Mägi, M., 2015. Chapter 4. Bound for the Eastern Baltic: Trade and Centres AD 800-1200. In: J. Barrett, S. Gibbon, eds. Maritime Societies of the Viking and Medieval World. Maney Publishing, 41-61.

Mckinley, J. and Bond, J.M., 2001. Cremated Bone. In: D.R. Brothwell, A.M. Pollard, eds. Handbook of Archaeological Sciences. Chichester: Wiley and Sons.

Miola, A., 2012. Tools for non-pollen palynomorphs (NPPs) analysis: a list of Quaternary NPP types and reference litera- 
ture in English language (1972-2011). Review of Palaeobotany and Palynology, 186, 142-161.

Mugurēvičs, E.., 1968. Kapu veidi Kurzemē agrā feodālisma periodā. In: Zinātniskās atskaites sesijas referātu tēzes par arheologu, antropologu un etnogräfu 1967. gada pētījumu rezultātiem. Rīga: Latvijas vēstures institūts, 18-21.

Mugurēvičs, Ē., 1999. Novadu veidošanās un to robežas Latvijas teritorijā (12.-16.gs. vidus). In: A. Caune, ed. Latvijas zemju robežas 1000 gados. Rīga: Latvijas vēstures institūta apgāds, 54-90.

Muižnieks, V., 2008. 14., 15. gs. Ugunskapi Kurzemē. 14th and 15 th century cremation burials in Kurzeme. In: V. Muižnieks, ed. Pètījumi kuršu senatnē: rakstu krājums. Rīga: Latvijas Nacionālais vēstures muzejs, 35-56.

Muižnieks, V., 2016. Bēru tradīijas Latvijā pēc arheologiski pētìto 14.-18. gs. apbedī̌̌anas vietu materiāla. Rīga: Latvijas Nacionālais vēstures muzejs.

Nomals, P., 1942. Sārnates purvs un tā techniskās izmantošanas projekts. Sarnate-Moor und Projekt seiner technischen Ausbeutung. Rīga: Zemes bagātību pētīšanas inst.

Piperno, D.R., 2016. Phytoliths: A comprehensive guide for archaeologists and paleoecologists. New York: Altamira Press.

Rashid, I., Mir, S.H., Zurro, D., Dar, R.A. and Reshi, Z.A., 2019. Phytoliths as proxies of the past. Earth-Science Reviews, 194, 234-250.

Schweingruber, F.H., 1982. Microscopic wood anatomy. Birmensdorf: Swiss Federal Institute of Forest, Snow and Landscape Research.

Shumilovskikh, L.S., Schlütz, F., Achterberg, I., Kvitkina, A., Bauerochse, A. and Leuschner, H.H., 2015. Pollen as nutrient source in Holocene ombrotrophic bogs. Review of Palaeobotany and Palynology, 221, 171-178.

Sigvallius, B., 2005. Viking Sweden. In: D.J. Davies, L.H. Mates, eds. Encyclopedia of cremation. Aldershot: Ashgate, 13-415.

Stivrins, N., Brown, A., Veski, S., Ratniece, V., Heinsalu, A., Austin, J., Liiv, M. and Cerina, A., 2016. Palaeoenvironmental evidence for the impact of the crusades on the local and regional environment of medieval (13th-16th century) northern Latvia, eastern Baltic. The Holocene, 26, 61-69.

Stockmarr, J., 1977. Tablets with spores used in absolute pollen analysis. Pollen et Spores, 13, 615-621.

Šnē, A., 2002. Kādas sabiedrības portrets: Sāraju senkapi un sociālpolitiskās attiecības Kurzemē aizvēstures beigās. In: A. Vijups, ed. Ventspils muzeja raksti. Rīga, 2, 128-155.

Šnē, A., 2011. Pāreja no aizvēstures uz vēsturiskajiem laikiem: viduslaiku sākuma problēma Austrumbaltijas reǵionā. Diskusija par viduslaiku un agro jauno laiku vēstures periodizācijas problēmām. Latvijas Vēstures Institūta Žurnāls, 2 (79), 135140.

Šturms, E., 1935. Talsu novada aizvēsture (Talsu novads I grāmatas atseviš̌ks novilkums). Rīga.

Šturms, E., 1938. Chroniku un senrakstu ziņas par baltu tautu bēru paražām 13 un 14.gs. In: B.Z. Ābers, T. Zeids, T. Zemzars, eds. Tautas vēsturei: veltījums profesoram Arvedam Švābem. 25.V 188.-25 V 1938. Rīga: A. Gulbis, 84-110.

Švābe, A., 1938. Straumes un avoti I. Grāmatu apgādniecība A. Gulbis. Rīgā.

Tomsons, A., 2018. Zobeni Latvijas teritorijā 7.-16. gs. Rīga: Latvijas Nacionālais vēstures muzejs.

Urtāns, J., 2004. Skudra pie kalna: arheologa stāsti. Riga: Nordik.

Vaska, B., 2017. Rotas un ornaments Latvijā no 13.gs. lìdz 18.gs. vidum. Rìga: Latvijas Nacionālais vēstures muzejs.

Wickholm, A., 2005. The cremation cemeteries under flat ground - a representative of what? In: R.K.J. Leskovar, eds. Interpretierte Eisenzeiten. Studien zur Kulturgeschichte von
Oberösterreich, Folge 18. Oberöster-reichisches Landesmuseum). Linz, 31-40.

Žulkus, V., 2004. Kuršiai Baltijos jūros erdvèje. Vilnius: Versus Aureus.

\section{VAKARŲ LATVIJOS LAPIN̦I \\ KURŠIŲ KAPINYNO LAIDOJIMO \\ PAPROČIAI GELEŽIES AMŽIUJE \\ IR VIDURAMŽIAIS \\ (12-14/15 AMŽIAIS)}

\section{INGA DONIN,A, NORMUNDS STIVRINS, VALDIS BĒRZIN̦Š}

\section{Santrauka}

Straipsnyje analizuojamos kuršių laidojimo tradicijos Vakarų Latvijoje, remiantis XII-XIV/XV a. datuojamo plokštinio degintinio Lapiņi kapinyno duomenimis (1 pav.). Siekiama pateikti aiškesnių ižvalgų apie tokio tipo kapinynus Baltijos jūros regione, kai pagrindinis demesys skiriamas aptariamojo laikotarpio aplinkos sąlygoms ir ju kaitai. Mėginiai sporų-žiedadulkių ir ne žiedadulkių palinomorfologinei analizei buvo paimti iš dviejų degintinių kapų. Taip pat buvo atliekamas ir medžio anglies rūšinis nustatymas, kuris galëjo atskleisti, kokia mediena buvo naudojama Lapini kapinyne kremavimo procese.

Lapini archeologinis kompleksas yra vakarineje Latvijos dalyje, nutolęs nuo Baltijos jūros kranto apie 2 kilometrus. Tai ir akmens amžiaus gyvenvieté, ir vèlyvuoju geležies amžiumi ir viduramžiais datuojamas kapinynas. Šis kompleksas buvo smarkiai apardytas tiesiant kelią. Archeologiniai tyrimai čia vyko 2012, 2014 ir 2015 m., jiems vadovavo Valdis Bērziņš ir Inga Doniṇa. Iš ištirtų $110 \mathrm{~m}^{2}$, $40 \mathrm{~m}^{2}$ vietoje kapai buvo visiškai sunaikinti, kitose tirtose vietose suardymai buvo menkesni (2, 3 pav.). Pagal ištirtą plotą ir atsitiktinių radinių pasiskirstymą, manoma, kad kapinyno dydis galejo siekti $2000-3000 \mathrm{~m}^{2}$. Lapini kapinynas buvo įrengtas ant žemo smèlingo kalvagūbrio dešiniajame Sārnate pelkès pakraštyje.

Degintiniai kaulai šiame kapinyne buvo išbarstyti nemažoje teritorijoje ir atidengti iškart po humusingo dirvožemio sluoksniu. Tyrimų plote buvo išskirta 11 degintinių kapų (4 pav.). Kapų skiriamasis bruožas buvo iškart po dirvožemiu atsidengęs 1-20 cm storio anglingas sluoksnis, kuris ir laikytinas degintinio kapo vieta. Anglingo sluoksnio vietos (kapai), kurios turëjo aiškias ribas, užėmé nuo 1 iki $4 \mathrm{~m}^{2}$ plotą, o kai kurios buvo ir didesnès. Kapų orientavimo pagal pasaulio šalis taip pat nepastebèta.

Ginklus ịkapių kompleksuose reprezentuoja geležiniai kirviai, o darbo įrankius - skiltuvai. Taip pat aptikta ir pa- 
puošalų: segių, apyrankių, žiedų, antkaklių, kabučių (kryželis, nago ir apvalūs kabučiai); drabužių aksesuarų: batų sagčių, metalinių grandžių ir t. t.); sidabrinis Kuršo vyskupystès brakteatas ir lipdytų keraminių indų. Dauguma artefaktų buvo sudeginti kartu su mirusiuoju: jie sudegę, susilydę ar specialiai deformuoti (sulenkti, sulaužyti arba supjaustyti) (5-7 pav.). Kapuose aptinkama nedaug atskirų fragmentuotų sudegusių kaulų. Aptikti kalcinavę balti ir fragmentiški kaulai rodo, kad kremacija vyko aukštoje temperatūroje. Vis dar nèra aptikta šio laikotarpio gyvenvietė. Manoma, kad bendruomenè gyveno greta dabartinio Sārnate kaimo, kuris yra apie $2 \mathrm{~km}$ nuo kapinyno.

Žiedadulkių tyrimai atskleidè, kad kapinyno naudojimo laikotarpiu čia augo mišrus miškas, kuriame dominavo alksniai, pušys, eglès, beržai, guobos, augo įvairios žolès. Greta jų augo ir lazdynai, ąžuolai, viržinių šeimos augalai (Ericaceae), paparčiai (Polypodiaceae) (8, 9 pav.). Kremacijai kapinyne naudota pušies mediena, taip pat uosis, guoba, alksnis ir beržas (1 lentelè). 